Article

\title{
User Thermal Comfort in Historic Buildings: Evaluation of the Potential of Thermal Mass, Orientation, Evaporative Cooling and Ventilation
}

\author{
Mamdooh Alwetaishi 1,*(D), Ashraf Balabel 2,3, Ahmed Abdelhafiz 1,4 , Usama Issa 1,5, \\ Ibrahim Sharaky ${ }^{1,6}$, Amal Shamseldin ${ }^{1,7}$, Mohammed Al-Surf ${ }^{8}$, Mosleh Al-Harthi ${ }^{9}$ and \\ Mohamed Gadi ${ }^{10}$ \\ 1 Civil Engineering Department, College of Engineering, Taif University, P.O. Box 11099, Taif 21099, \\ Saudi Arabia; a.abdelhafiz@tu.edu.sa (A.A.); u.issa@tu.edu.sa (U.I.); i.sharaky@tu.edu.sa (I.S.); \\ ashamesldin@tu.edu.sa (A.S.) \\ 2 Mechanical Engineering Department, College of Engineering, Taif University, P.O. Box 11099, Taif 21099, \\ Saudi Arabia; a.balabel@tu.edu.sa \\ 3 Mechanical Engineering Department, College of Engineering, Menofia University, Menofia 32511, Egypt \\ 4 Civil Engineering Department, College of Engineering, Assiut University, Assiut 71515, Egypt \\ 5 Civil Engineering Department, College of Engineering, Minia University, Minia 61111, Egypt \\ 6 Material Engineering Department, College of Engineering, Zagazig University, Zagazig 44519, Egypt \\ 7 Department of Archtectural Engineering, College of Engineering, Ain Shams University, Cairo 11566, Egypt \\ 8 U.S. Green Building Council and Green Business Certification Institute, Washington, DC 20037, USA; \\ malsurf@gbci.org \\ 9 Electrical Engineering Department, College of Engineering, Taif University, P.O. Box 11099, Taif 21099, \\ Saudi Arabia; m.harthi@tu.edu.sa \\ 10 Department of Architecture Built Environment, Faculty of Engineering, The University of Nottingham, \\ Nottingham NG7 2RD, UK; mohamed.gadi@nottingham.ac.uk \\ * Correspondence: m.alwetaishi@tu.edu.sa
}

Received: 24 October 2020; Accepted: 17 November 2020; Published: 19 November 2020

\begin{abstract}
The study investigated the level of thermal comfort in historical buildings located at a relatively high altitude in the Arabian Desert of Saudi Arabia. The study focused on the impact of the use of thermal mass and orientation on the level of thermal performance at Shubra and Boqri Palaces. Qualitative and quantitative analyses were used in this study, including a questionnaire interview with architecture experts living at the relatively high altitude of Taif city, to obtain data and information from local experts. The computer software TAS EDSL was used along with on-site equipment, such as thermal imaging cameras and data loggers, to observe the physical conditions of the building in terms of its thermal performance. The study revealed that the experts' age and years of experience were important aspects while collecting data from them during the survey. The use of thermal mass had a slight impact on the indoor air temperature as well as the energy consumption, but it helped in providing thermal comfort. Use of ventilation can improve thermal comfort level. Evaporative cooling technique has a considerable impact on reducing indoor air temperature with $4{ }^{\circ} \mathrm{C}$ drop, improving the thermal comfort sensation level. The novelty of this work is that, it links the outcomes of qualitative results of experts with field monitoring as well as computer modelling. This can contribute as method to accurately collect data in similar case studies.
\end{abstract}

Keywords: historical buildings; thermal mass; orientation; hot regions; evaporative cooling; ventilation 


\section{Introduction}

\subsection{Background}

Buildings should be constructed with consideration of the local microclimate conditions at a given location, particularly when dealing with thermal comfort, which relies heavily on location and culture [1]. Thus far, many passive strategies have been proposed to improve the energy building performance and comfort, such as thermal mass, window to wall ratio (WWR), SHGC, building geometry, orientation, and layout [2-4]. Several researchers have investigated the influence of low-E glazing, which aids in improving energy consumption as well as internal visual comfort [5]. WWR is a significant element for energy use for cooling, and to a less extent, ventilation and daylight [6]. Solar radiation is a leading factor affected by the solar coefficient as well as WWR [7].

\subsection{Impact of Window to Wall Ratio (WWR)}

With respect to the hot and dry climate of Saudi Arabia (Figure 1), Alwetaishi [8] explored the impact of WWR in the different climatic zones of Saudi Arabia. The results determined that WWR in hot regions should not exceed $10 \%$ in all the directions; however, the impact of this opening size on de-lighting was unclear. Moreover, another study was conducted in a similar climate of Libya [9]. This study revealed that an increase in the WWR on the south-side led to an increase in the energy load in summer and a nearly zero demand of heating in winter. In another study reported in [10], in the hot climate of Libya, an increase in the WWR resulted in an increase in the cooling energy in summer and a reduction to nearly zero carbon energy in winter. However, the amount of cooling energy generated by the increase in the WWR was greater than that of the energy saved in winter, which led to the overall increase in the annual energy consumption. Even in cold climate, there is a significant influence of windows in the form of solar heat gain [11].

Thus, each direction would have a different WWR depending on the local climate (Figure 2 shows different climatic zones in Saudi Arabia), which is very similar to the findings of Alwetaishi [11], where each direction within the same building was designed according to the diversity of the solar radiation exposed to the outer surface of each direction. The study revealed that the south and west orientations should have their glazing minimised as compared to the east and north ones. Similarly, Asfour [12] studied the impact of de-lighting and having a courtyard, considering the hot and dry climate of Saudi Arabia; he recommended that the WWR should be minimised and the usage of external shading devices should be encouraged. In addition, the study also highlighted that increasing the WWR in such a region to more than $50 \%$ will only lead to an increase in the cooling demand as well as in the glare, which will ultimately affect human comfort. Alshuhail [13] investigated the influence of orientation on thermal performance in an experimental study performed in the hot and dry climate of the UAE. This study revealed that the south orientation has a $9.4 \%$ higher temperature than the north.

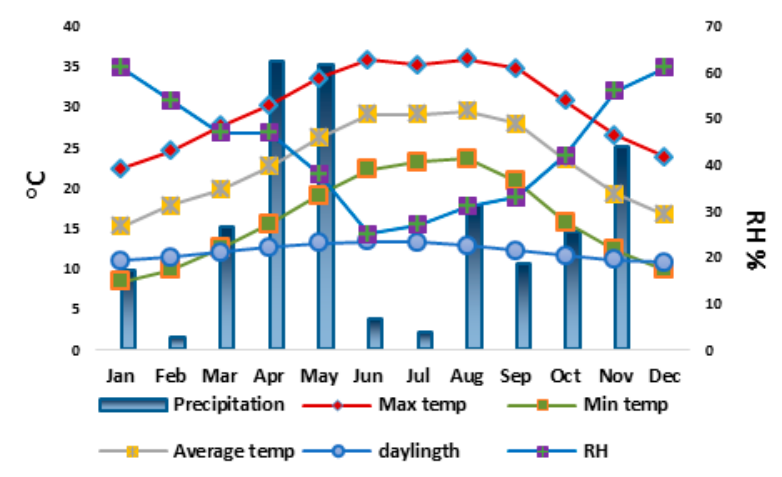

Figure 1. Climate of Taif city, reproduced from the .epw file derived from Alwetaishi [11]. 


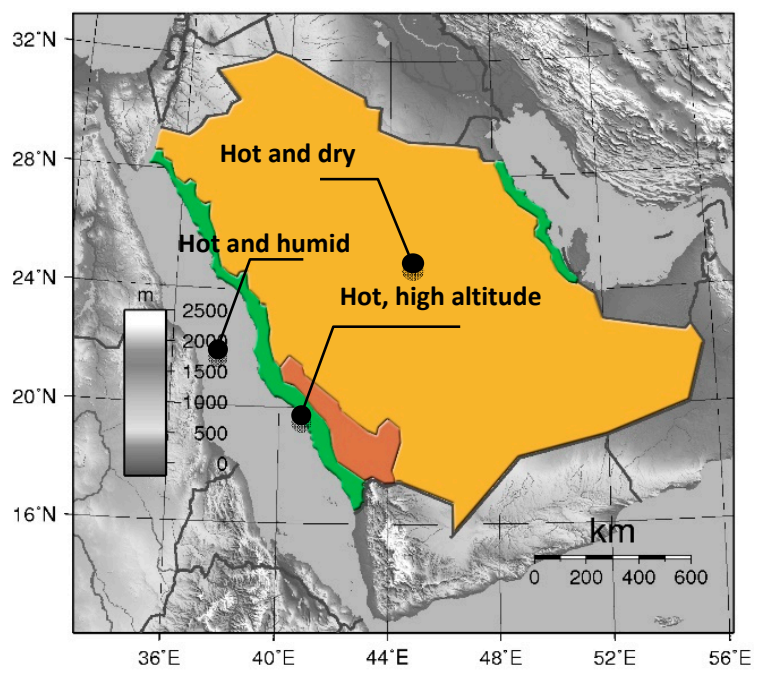

Figure 2. Major climatic zones in Saudi Arabia based on temperature, humidity, and altitude, as introduced by Alwetaishi [8].

In contrast, another study reported in [14] investigated the impact of orientation on the indoor thermal environment in the hot and humid climate of Singapore. This work highlighted that the north and the south orientations are preferred for providing thermal comfort over the east and the west ones. Su [15] stated that a single glazing window models a higher influence on the energy demand than any other aspect, while low-E could considerably improve the lifecycle energy performance of the building. In addition, the WWR should be precisely highlighted, as it increases the energy demand even in regions with a relatively cool climate [16-18]. Note that the type of glazing has a greater impact on the energy demand in hot countries than the orientation, building shape, and storey level [19]. Shahbazi [20] introduced a new tool to optimise the glazing system by using a parametric study. In cold regions, the WWR may affect the solar gain and the daylight in winter when passive solar heat is required; however, it may lead to overheating in summer [21]. As a result, the WWR should be designed carefully even in cold regions (Table 1 highlights recent publications in the topics of thermal mass, orientation and WWR) while Figure 3 present flow chart of study

Table 1. Selection of recent studies on thermal mass, orientation, and WWR.

\begin{tabular}{|c|c|c|c|c|c|}
\hline Ref. & Year & Country & Climate & Method & Major Findings \\
\hline [22] & 2020 & Italy & Mediterranean & Review paper & $\begin{array}{l}\text { Thermal mass and night ventilation can } \\
\text { improve energy consumption in the case } \\
\text { of retrofitted heritage buildings }\end{array}$ \\
\hline [23] & 2020 & Spain & Mediterranean & $\begin{array}{l}\text { Photovoltaic } \\
\text { electrical } \\
\text { self-system }\end{array}$ & $\begin{array}{l}\text { It can reduce amount of energy } \\
\text { consumption from } 60-80 \%\end{array}$ \\
\hline [24] & 2020 & Turkey & Black sea & Experimental & $\begin{array}{l}\text { Use of night ventilation and thermal mass } \\
\text { can reduce energy consumption by } 27 \%\end{array}$ \\
\hline [25] & 2020 & Germany & Temperate & $\begin{array}{l}\text { Model predictive } \\
\text { control } \\
\text { (algorithm) }\end{array}$ & $\begin{array}{l}\text { The use of thermal mass can reduce the } \\
\text { energy demand by } 3-7 \% \text {, and it is } \\
\text { considerably linked to the thermal } \\
\text { comfort level. }\end{array}$ \\
\hline [19] & 2020 & Saudi Arabia & Hot and dry & $\begin{array}{l}\text { AEISS, } \\
\text { ECOTECT, BIM, } \\
\text { Revit }\end{array}$ & $\begin{array}{l}\text { Window glazing has a considerable } \\
\text { impact on the cooling load in hot regions } \\
\text { as compared to other aspects such as } \\
\text { orientation, building shape, } \\
\text { and storey level. }\end{array}$ \\
\hline
\end{tabular}


Table 1. Cont.

\begin{tabular}{|c|c|c|c|c|c|}
\hline Ref. & Year & Country & Climate & Method & Major Findings \\
\hline [26] & 2019 & Australia & Temperate & $\begin{array}{l}\text { IDA and ICE } \\
\text { computer } \\
\text { software }\end{array}$ & $\begin{array}{l}\text { The use of thermal mass through various } \\
\text { wall and flooring systems can reduce the } \\
\text { energy demand by up to } 58 \% \text {. }\end{array}$ \\
\hline [12] & 2020 & Saudi Arabia & Hot and dry & $\begin{array}{l}\text { EnergyPlus, } \\
\text { Radiance }\end{array}$ & $\begin{array}{l}\text { It is recommended to use shading } \\
\text { devices, courtyard, and atrium to } \\
\text { control the sunlight in hot regions. } \\
\text { The optimum WWR is } 30 \% \text { with the } \\
\text { use of a shading device. } \\
\text { Increasing the WWR to a value higher } \\
\text { than } 50 \% \text { will impact glare and } \\
\text { increase the cooling demand in a } \\
\text { hot region. }\end{array}$ \\
\hline [13] & 2020 & UAE & Hot and dry & $\begin{array}{l}\text { Measuring } \\
\text { equipment }\end{array}$ & $\begin{array}{l}\text { South-facing rooms have } 9.5 \% \text { higher } \\
\text { temperatures than the north-facing ones. }\end{array}$ \\
\hline [11] & 2020 & Saudi Arabia & Hot and dry & $\begin{array}{l}\text { Measuring } \\
\text { equipment, TAS } \\
\text { EDSL computer } \\
\text { modelling }\end{array}$ & $\begin{array}{c}\text { It is recommended to have a WWR of } 35 \% \\
\text { for north-west-facing rooms, } 25 \% \text { for } \\
\text { south-east-facing rooms, and } 20 \% \text { for } \\
\text { south-west-facing rooms. }\end{array}$ \\
\hline [27] & 2019 & China & Temperate & $\begin{array}{l}\text { Proposed model } \\
\text { based on control }\end{array}$ & $\begin{array}{l}\text { The use of thermal mass in this region can } \\
\text { save up to } 7.23 \% \text { energy. }\end{array}$ \\
\hline [28] & 2019 & Portugal & Mediterranean & EnergyPlus & $\begin{array}{l}\text { - Thermal transmittance (TT) can vary } \\
\text { depending on the location of the } \\
\text { building. Istanbul for instance, might } \\
\text { have a variation of TT of }-0.73 \% \text { to } \\
4.21 \% \text {, while Casablanca was found } \\
\text { to be in the range of }-5.66 \% \text { to } 6.96 \% \text {. } \\
\text { The determination of the impact of } \\
\text { thermal mass is very complex, and the } \\
\text { amount of TM has to be identified on } \\
\text { the basis of TT. }\end{array}$ \\
\hline [29] & 2019 & China & $\begin{array}{l}\text { Hot summer and } \\
\text { cold winter }\end{array}$ & $\begin{array}{l}\text { State-space } \\
\text { model }\end{array}$ & $\begin{array}{l}\text { A high thermal mass has no effect on the } \\
\text { energy demand, but it helps to improve the } \\
\text { thermal comfort for the users. }\end{array}$ \\
\hline [30] & 2018 & India & Composite & $\begin{array}{l}\text { Experimental } \\
\text { study }\end{array}$ & $\begin{array}{l}\text { The use of thermal mass can aid to improve } \\
\text { the thermal comfort from } 40 \% \text { to } 98 \% \text { in } \\
\text { summer and winter, respectively. }\end{array}$ \\
\hline [31] & 2017 & Ireland & $\begin{array}{l}\text { Hot and cold } \\
\text { climates }\end{array}$ & $\begin{array}{l}\text { Transient energy } \\
\text { ratio method }\end{array}$ & $\begin{array}{l}\text { The use of thermal mass is more likely to be } \\
\text { effective in hot countries. }\end{array}$ \\
\hline [7] & 2013 & Malaysia & Hot and humid & $\begin{array}{l}\text { Measuring } \\
\text { equipment }\end{array}$ & $\begin{array}{l}\text { Reduction of the amount of solar } \\
\text { radiation is the leading factor in } \\
\text { building heat transfer. } \\
\text { Solar radiation is affected by the } \\
\text { WWR and the solar coefficient. }\end{array}$ \\
\hline
\end{tabular}

\subsection{Significance of Thermal Mass in Buildings}

Thermal mass (TM) can be classified into two major groups: internal TM, such as furniture, and external TM, such as walls, roofs, and floors [32]. The use of TM can be effective in reducing the total amount of energy and maintaining the thermal comfort levels for the users [23,26,30-32]. TM is the most functional in hot weather when outdoor temperatures soar sharply [31] or in hot summer in cooler regions [25,26,28,33-35]. Kumar [36] argued that the use of thermal mass is not beneficial only in summer but also in the composite climate of India in winter. Furthermore, Rodrigues [28] investigated the relationship between energy consumption and thermal mass in the Mediterranean climate and found that thermal transmittance varies on the basis of the local climate. For instance, the variation of thermal transmittance was as low as $(-0.99 \%$ to $+3.89 \%)$ in Marseille in France and was as high 
as $(-1.81 \%$ to $5.44 \%)$ in Tel Aviv. This work also highlighted the importance of the effect of thermal transmittance on the thermal mass performance. A comparison between a historical building built of stone with a modern one built with bricks was carried out by Yousef [37] in the hot climate of Egypt. This study indicated that the use of a historical building helps to lower the indoor air temperature by $1.4{ }^{\circ} \mathrm{C}$. Furthermore, there many publications which are conducted based on a case study of heritage buildings such as $[38,39]$.

Thermal mass is strongly connected to thermal comfort. According to Kumar [30], 40\% to $98 \%$ of thermal discomfort can be avoided when using thermal mass in buildings. In fact, some of the published work argues that the use of TM will not aid in reducing the energy demand but will help to improve the thermal comfort level for users [29]. A new design formula was introduced by Li [40] to be used by architects and engineers; it includes three parameters, namely the time constant of the system, the dimensionless convective heat transfer number, and the Fourier time constant.

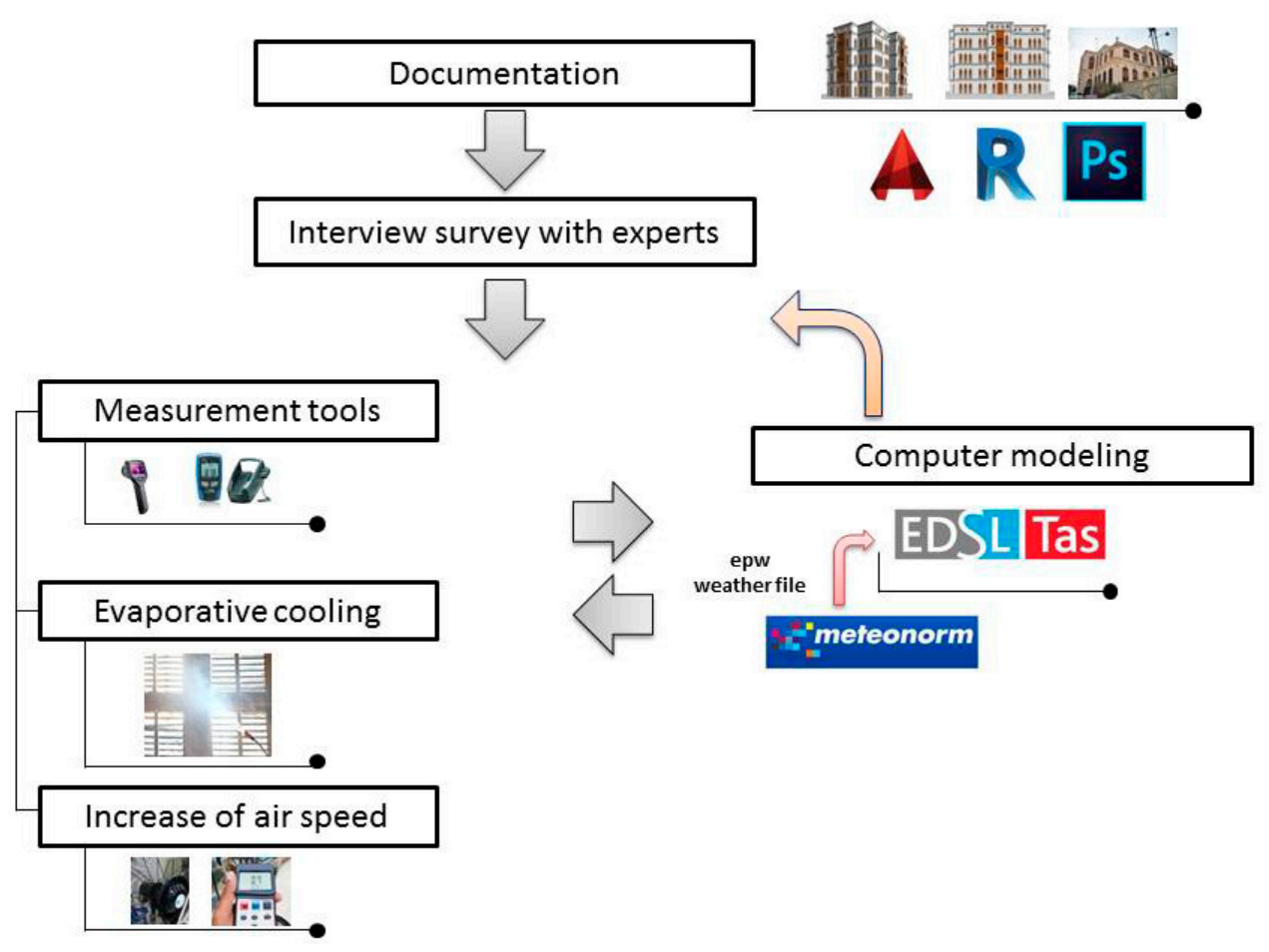

Figure 3. Flow chart of the methodology.

\subsection{Evaporative Cooling in Buildings}

Evaporative cooling is a widely used method for cooling especially in hot regions [41,42]. In a study conducted by [43] in a hot region, it was found that the use of ventilated wall cavity using spray evaporative cooling system can reduce temperature of outdoor from $45{ }^{\circ} \mathrm{C}$ to $25^{\circ} \mathrm{C}$. In addition to that, the work of Alaa [44] indicated that the same system can reduce the amount of cooling load by $23 \%$. In a study carried out by Bagasi [45] where authors used different techniques for indoor evaporative cooling systems in a hot and humid climate. They found that evaporative cooling system using wet cloth can reduced indoor air temperature by $26.3 \%$. However, high relative humidity was observed during the study due to the climate which is hot and humid. There are several some other methods for evaporative cooling such as spray passive Downdraft evaporative cooling (PDEC) which has been intensively investigated such as the work of Kang [46]. In a study conducted by Ana [47] highlighted that use of evaporative cooling systems can achieve thermal comfort level with a free running operation system in the climate of Spain. This study used wide range of tools to conduct the study, Table 2 indicates equipment used. 
Table 2. Specifications of the tools used in the study.

\begin{tabular}{ccc}
\hline Sensor/Tool & Output \\
$\begin{array}{c}\text { Thermal imaging } \\
\text { photographs }\end{array}$ & $\begin{array}{c}\text { Temperature range from }-20 \text { to } \\
250{ }^{\circ} \mathrm{C}\left(-4 \text { to } 482^{\circ} \mathrm{F}\right)\end{array}$ \\
$\begin{array}{c}\text { Temperature and } \\
\text { humidity data logger }\end{array}$ & $-\quad \begin{array}{c}\text { Built-in sensor to measure } \\
\text { temperature and humidity } \\
\begin{array}{c}\text { TAS; energy building } \\
\text { performance tool }\end{array} \\
\text { Energy analysis, daylight, } \\
\text { thermal comfort, etc. } \\
\text { Watering Sprayer }\end{array}$ \\
To moisturize the air \\
Air fan
\end{tabular}

\subsection{Case Study and Shubra Palace Documentation Contribution}

Shubra Palace is considered the most important historical building in the city of Taif and is one of the most important old buildings in Saudi Arabia (Figures 4 and 5).

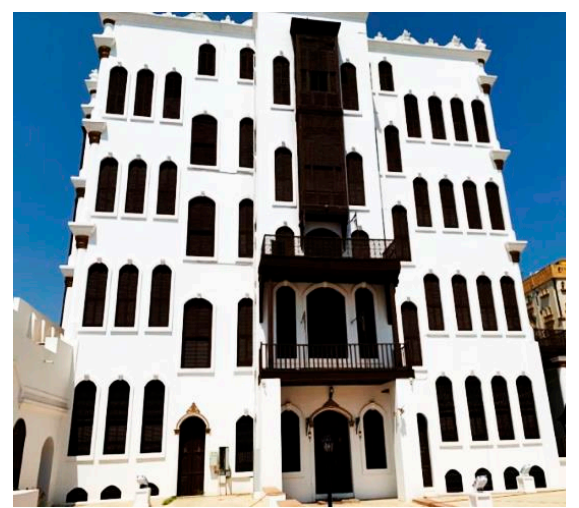

(A)

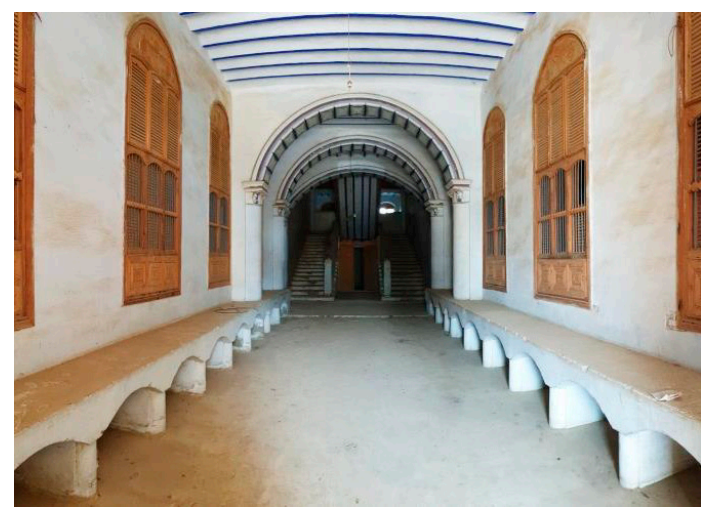

(B)

Figure 4. Photograph of Shubra Palace (A) and (B) Boqari Palace (entrance hall), (Source: authors).

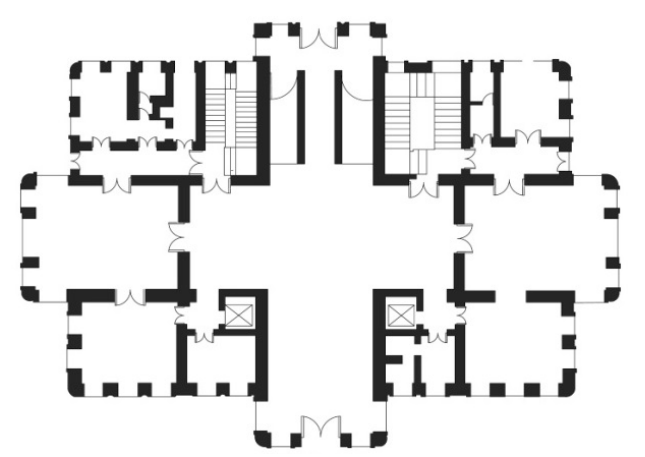

(A)

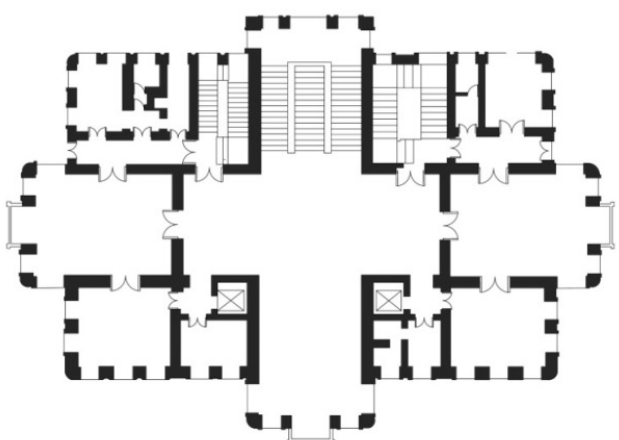

(B)

Figure 5. Cont. 


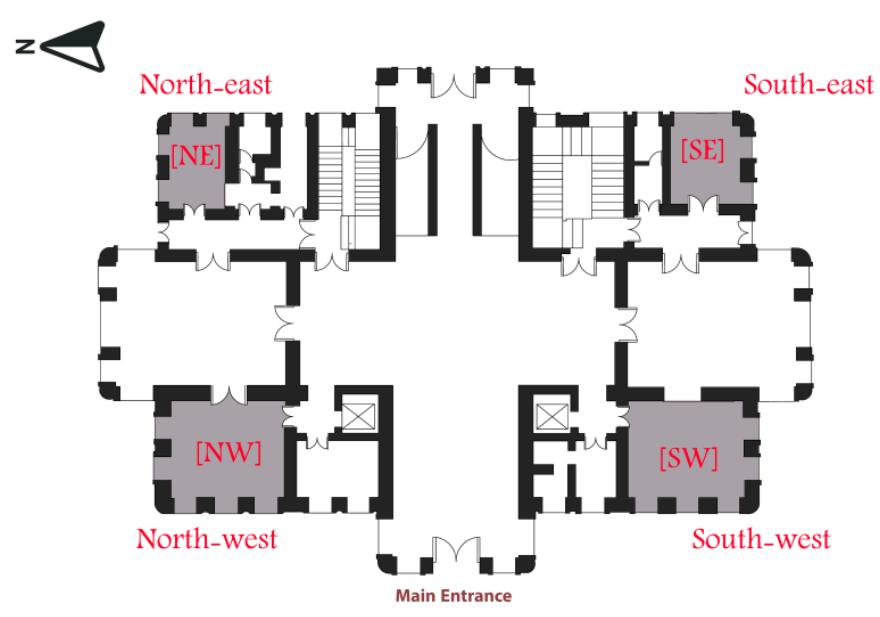

(C)

Figure 5. Plans of the palace produced by the research team of the current study: (A) ground and first floor levels (office and work), (B) typical design for second and third levels (family residence design levels), and (C) location of each of the rooms examined.

\section{Method and Material of Study}

According to Arab news [48], the palace was built in 1907, and it is the first historical building in the city of Taif. It has a museum section attached to it, which represents three major periods of before Islam, Stone Age to Jahiliya period; Islamic heritage; and the unification of the Kingdom. It also contains a large number of valuable artefacts. The palace used to be the residence for King Faisal and his office. This made the building quite important with a valuable historical background. Unfortunately, as the building is quite old, no architectural drawings of this building exist. As a result, the first mission to the research group was to provide all the architectural drawings of the palace (Figures 5-7). These documents are considerably important to be conserved in the palace, displayed in the museum, and used in future research. In addition to that, Boqari Palace also is considered one of the most important historical buildings in Taif city which was built about 100 years ago. The palace is located in the heart of the city and it was made of stone. The Palaces were monitored using number of tools listed in Table 2. The study investigated the case studies presented in Figures 6 and 7 along with conducting a survey designed for experts is that both methods were aiming to highlight historical buildings. This will provide a comprehensive investigation to link the two methods all together.

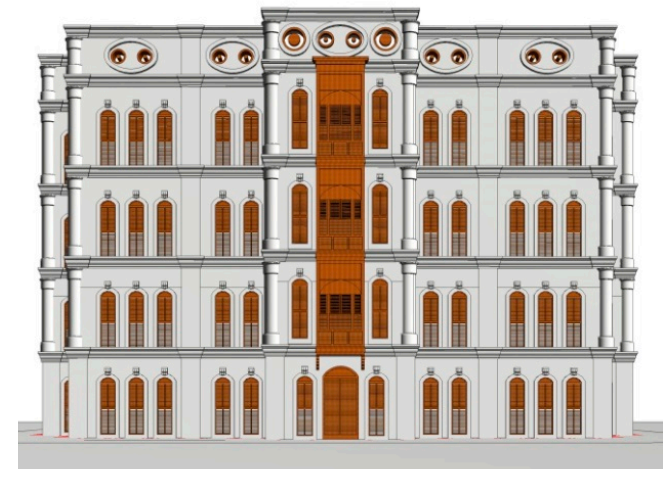

(A)

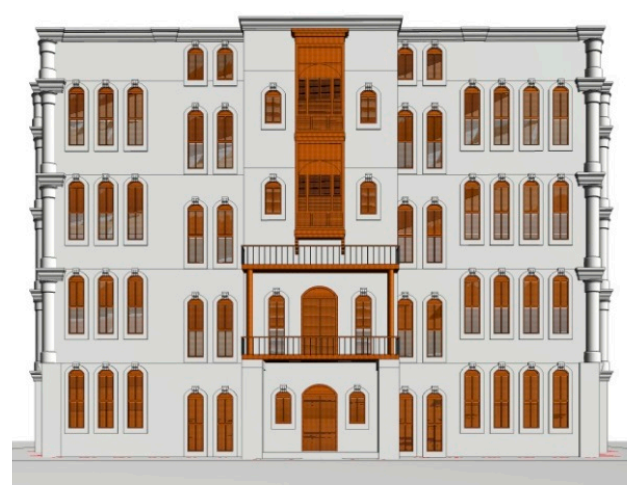

(B)

Figure 6. Cont. 


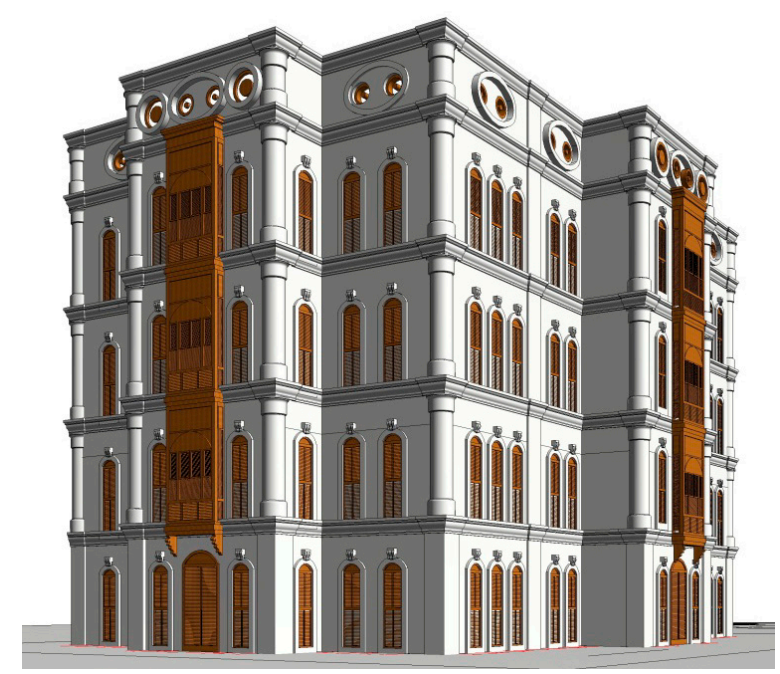

(C)

Figure 6. Views of the palace produced by the research team using AutoCAD and Revit: (A) main entrance (west), (B) side entrance leading to the house (east), and (C) 3D view of the palace.

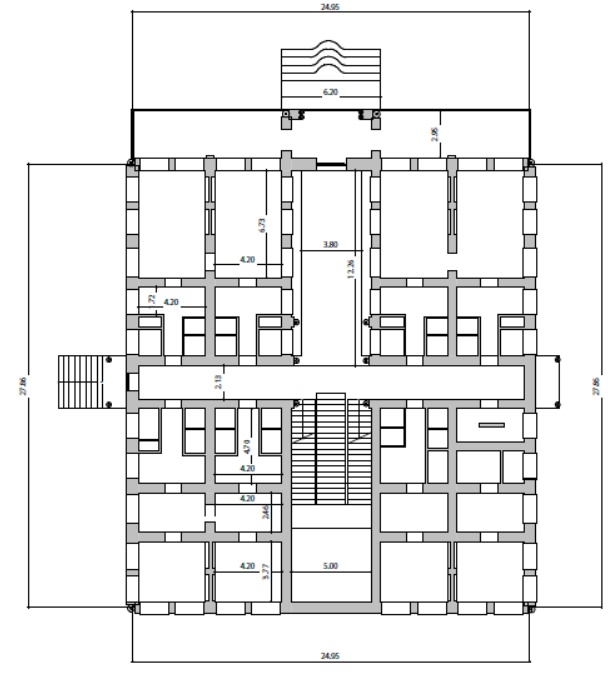

(A)

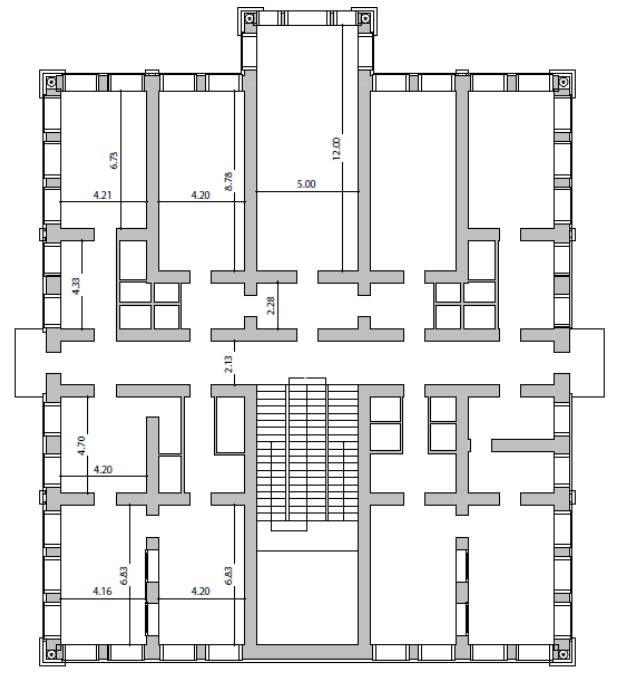

(B)

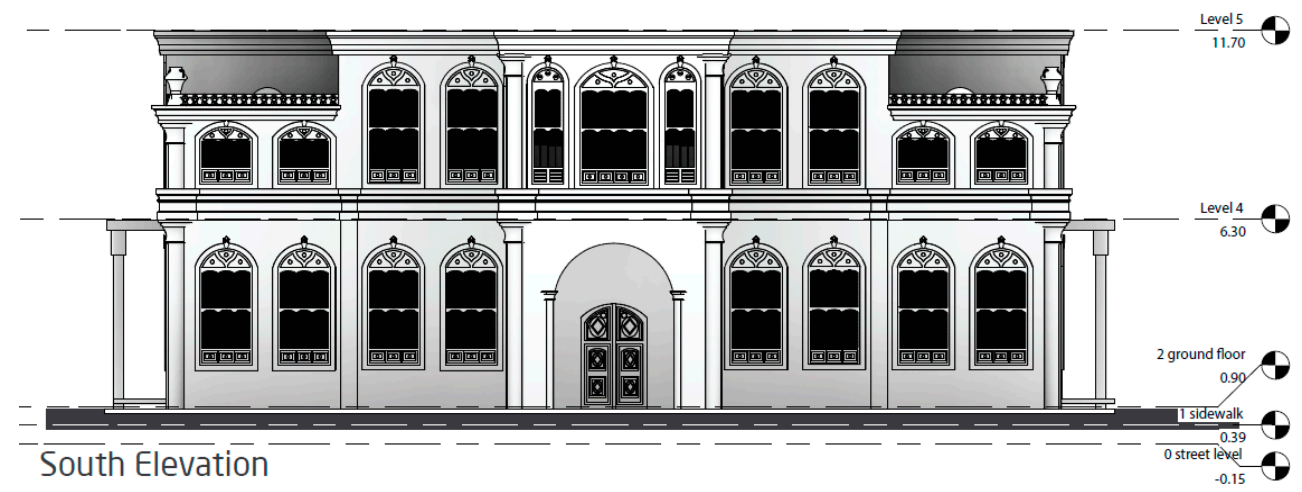

(C)

Figure 7. Elevation and plans of Boqari Palace $(\mathbf{A}-\mathbf{C})$.

\subsection{Questionnaire Design and Sample Size}

This study aimed to collect the opinions of experts in architecture and of those who were interested in historical buildings and to compare these data with the results of computer modelling as well as the 
used equipment such as thermal imaging cameras and data loggers. The sample size of the survey was 171 with a vast majority of architecture experts. Approximately $87.3 \%$ of the sample lived in the high altitude city of Taif. Table 3 shows the design and content of the questionnaire, which aimed to observe the achievement of thermal comfort in the high-altitude mountain regions of Saudi Arabia, such as the cities of Taif, Abha, and Baha (Figure 1). Most of the people living there were influenced by the local behaviour of relying on air conditioning systems even though it might not be necessary. The participated people were interviewed during November and December of 2019. Most of them were visited in their places of work to set up the interview. However, some other who based in the city of Abha which is very far away from Taif city conducted an online interview.

Table 3. Items of the questionnaire sheet designed particularly for architecture experts.

\begin{tabular}{llr}
\hline & \multicolumn{1}{c}{ Item/Statement } & \multicolumn{1}{c}{ Content } \\
\hline 1. $\begin{array}{l}\text { Personal information } \\
\text { 2. } \begin{array}{l}\text { I believe that old and historical buildings in } \\
\text { Saudi Arabia are better than modern buildings } \\
\text { with respect to providing thermal comfort to } \\
\text { the users. }\end{array}\end{array}$ & $\begin{array}{c}\text { Age, subject, years of experience, education level } \\
\text { Strongly agree, slightly agree, neutral, slightly } \\
\text { disagree, strongly disagree }\end{array}$ \\
3. $\begin{array}{l}\text { Can old and historical buildings provide } \\
\text { thermal comfort to the users without the use } \\
\text { of ACs? }\end{array}$ & $\begin{array}{l}\text { In winter, some seasons in the year, from time to time, } \\
\text { in higher altitude areas only, it is not possible at all }\end{array}$ \\
$\begin{array}{l}\text { What is the most important aspect that helps to } \\
\text { improve the thermal comfort in old and } \\
\text { historical buildings? }\end{array}$ & $\begin{array}{l}\text { Thermal mass, building orientation, WWR, other, } \\
\text { it does not provide thermal comfort }\end{array}$ \\
$\begin{array}{l}\text { Do you think that modern buildings in the } \\
\text { higher altitude areas in Saudi Arabia can } \\
\text { provide thermal comfort without the use } \\
\text { of ACs? }\end{array}$ & $\begin{array}{l}\text { In winter, some seasons in the year, from time to time, } \\
\text { in higher altitude areas only, it is not possible at all }\end{array}$ \\
$\begin{array}{l}\text { Do you think that old and historical buildings } \\
\text { in the higher altitude areas in Saudi Arabia can } \\
\text { provide thermal comfort without the use } \\
\text { of ACs? }\end{array}$ & $\begin{array}{c}\text { In winter, some seasons in the year, from time to time, } \\
\text { in higher altitude areas only, it is not possible at all }\end{array}$ \\
\hline
\end{tabular}

Various tools were used in this study, including computer modelling software and monitoring equipment. The study used TAS EDSL 9.4.1, which is considered to be one of the most widely used energy software packages to predict the thermal performance of buildings. This is a globally used software package used for energy analysis studies across the world, including Saudi Arabia [8], Singapore [49], Austria [50], Italy [51,52], Chile [53], Poland [54], the UK [46,55,56], and Turkey [57].

Some of the thermal elements were calculated on the basis of the building material of the Palace (Table 4), such as the solar heat gain, which was affected by the WWR and the type of glazing. It is very important to address the size and type of glazing in buildings in such a region [11]. In addition to this is the building heat transfer, which is affected by the type and the width of the building envelope. All of these variables resulted in the actual indoor air temperature. Haider [26] reported that the insulated glazing system, internal shading devices, natural ventilation, and the use of thermal mass lead to a total reduction of $22 \%$ in the energy demand. He also calculated the predicted mean vote using the macros tool EDSL and compared it to the monitored data and the survey data in the form of quantitative and qualitative data. 
Table 4. Building envelope characteristics of Shubra Palace.

\begin{tabular}{|c|c|c|c|c|}
\hline & Material & $\begin{array}{c}\text { Thickness } \\
\text { (mm) }\end{array}$ & $\begin{array}{l}\text { Conductivity } \\
\left(\mathrm{W} / \mathrm{m}^{\circ} \mathrm{K}\right)\end{array}$ & $\begin{array}{l}\text { Total U-Value } \\
\quad\left(\mathrm{W} / \mathrm{m}^{2} \mathrm{~K}\right)\end{array}$ \\
\hline \multicolumn{5}{|c|}{ Base case model (Palace as it is) } \\
\hline External wall & Stones & 450.00 & 1.31 & 1.4 \\
\hline \multirow{2}{*}{ Roof } & Wood bars & 88.00 & 0.11 & \multirow{2}{*}{0.44} \\
\hline & Mud & 200.00 & 0.87 & \\
\hline Ground & Stones & 450.00 & 1.31 & 1.4 \\
\hline \multicolumn{5}{|c|}{ Proposed model (Simulated, modern style building construction) } \\
\hline External wall & Concrete block & 200.00 & 1.31 & 3.1 \\
\hline \multirow{2}{*}{ Roof } & Thermal insulation & 125 & 0.04 & \multirow{2}{*}{0.22} \\
\hline & Concrete slap & 200 & 1.31 & \\
\hline \multirow{3}{*}{ Ground } & Concrete foundation & 300 & 0.87 & \multirow{3}{*}{0.35} \\
\hline & Crashed Aggregate & 75 & 0.55 & \\
\hline & Clay soil & 1000 & 0.70 & \\
\hline
\end{tabular}

2.2. Field Experiments (Evaporative Cooling and Increasing Indoor Air Speed to Improve Thermal Comfort Sensation)

Since Shubra palace windows were sealed to protect the palace and to switch the mechanical system to fully air conditioned, another extended field experiment were conducted in Boqari palace which is still a free running operation system. Both buildings were built with same building materials. The field experiment aimed to investigate the influence of evaporative cooling on indoor environment of the palace as well as increasing indoor air speed in summer. The experiment conducted on 29 August in 2020 .

\subsection{Calibration of the Energy Model and Validation}

Since 1970s, building simulation is becoming an aid to emulate reality [58]. There are so many input data associated with energy building simulation [59]. The study used graphical calibration to justify the accuracy of software. Figure 8 indicated a presentation between measured and simulated figures of temperature and humidity using data-loggers. Actual monitored outdoor temperatures also recorded and applied in the software for proper comparison. Acceptable results found out which are within the tolerances. As a result, TAS EDSL energy model can be used as well-calibrated software. Moreover, the TAS EDSL software has been validated previously by the author in another study converged on the use of sustainable application of an asphalt mixes (RAP) [60]. A real prototype model has been compared to a simulated one in the software (Figure 9).

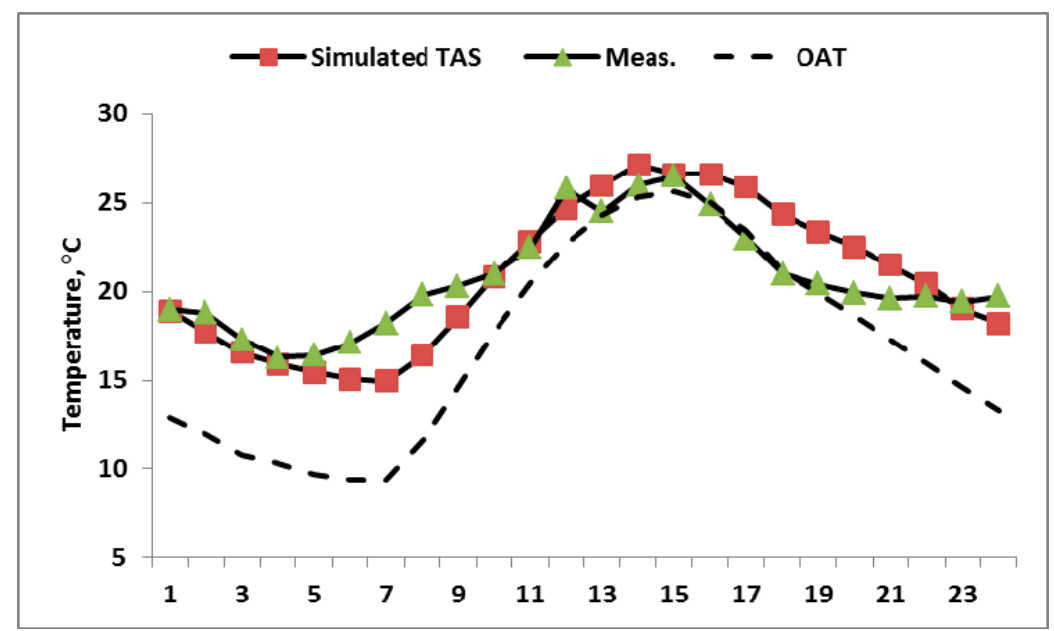

(A)

Figure 8. Cont. 


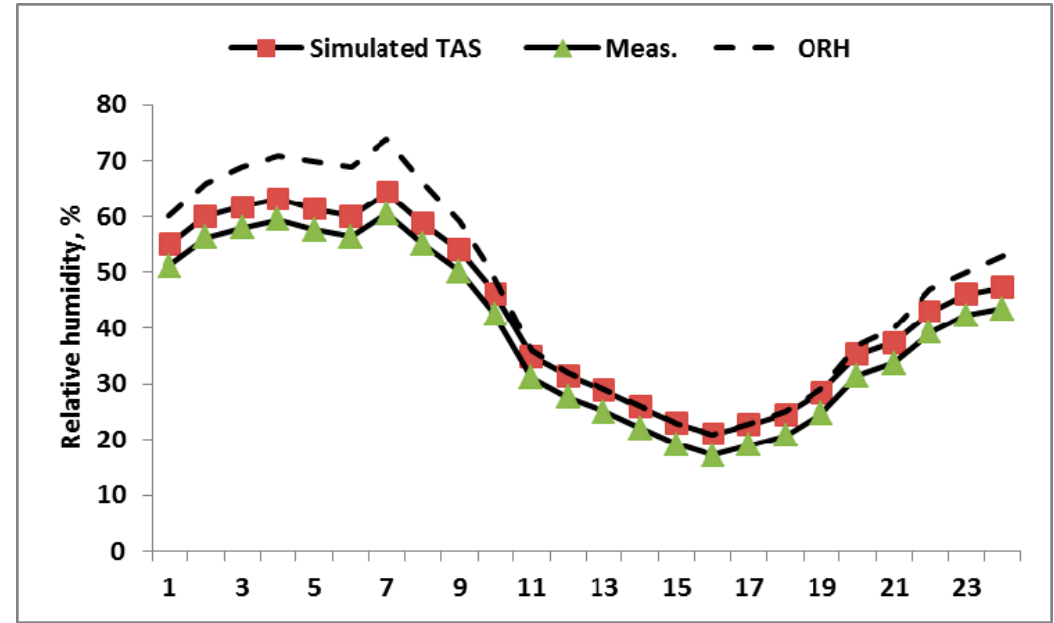

(B)

Figure 8. Calibration: Indoor temperatures (A) and relative humidity (B).
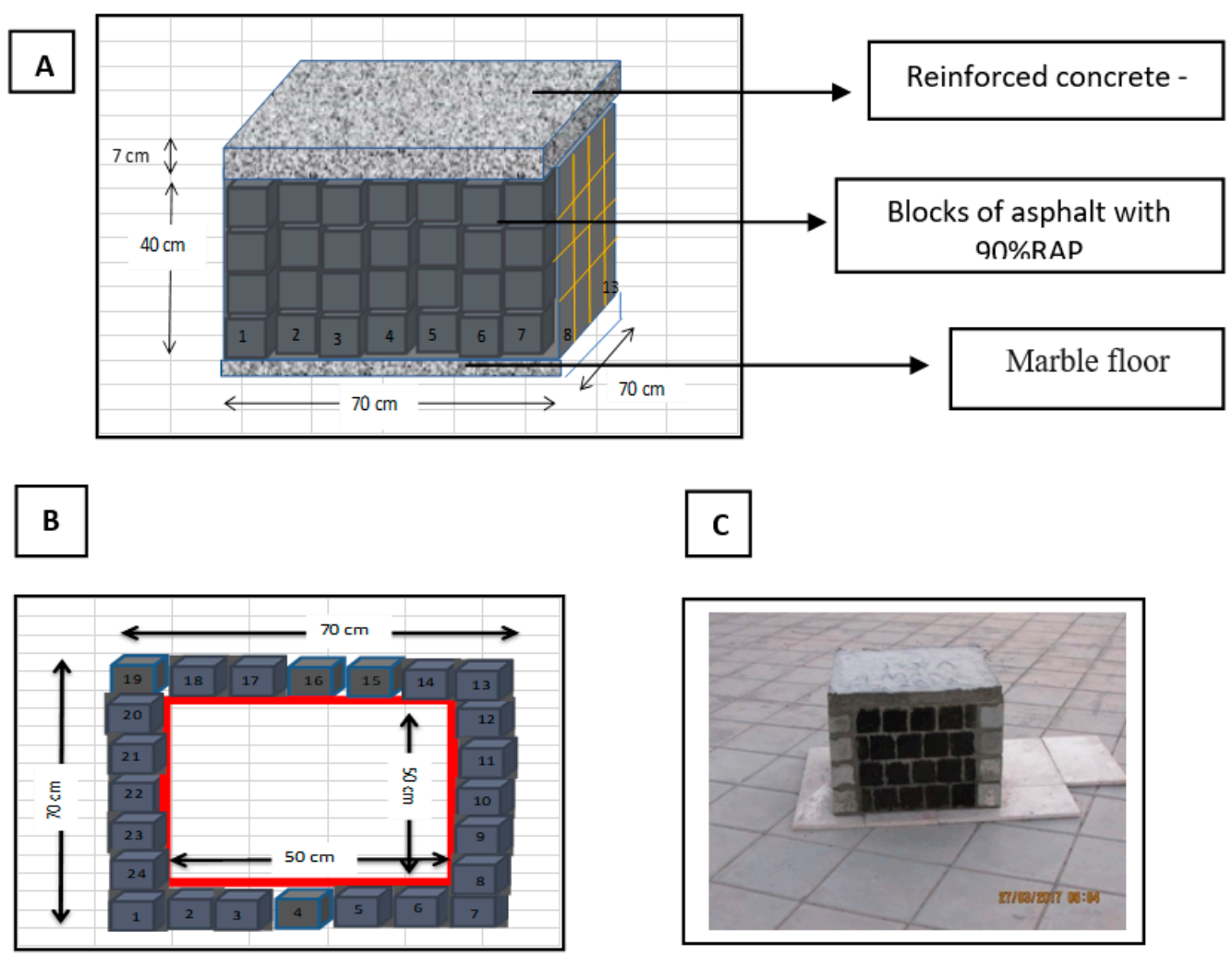

Figure 9. Validated model for TAS EDSL; where: (A) is the 3D model, $(\mathbf{B})$ is the plan side and (C) is a view of the actual model [61].

\section{Results and Discussion}

One of the major contributions and findings of this research was to explore the feedback of specialists in the field of architecture as the qualitative data to be compared with the quantitative ones, which were in the form of the monitoring and the calculated data. The research aimed to question as many of architects as possible who were living in the city of Taif or a similar climatic zone in Saudi Arabia (Figures 1 and 2), which was considered to be a hot region at a relatively high altitude. This made the climate pleasant in summer as compared to the hot areas in the Middle East. In addition, the questionnaire aimed to identify several parameters, such as age, years of experience, and level of 
education, that might affect the feedback of the specialists. These data helped to analyse the other data more precisely. Table 3 shows the design of the questionnaire including the items and contents.

Figure 10 indicates the age of the participating experts in the survey. The sample size was 171, and a vast majority of the participants were architects, $87.3 \%$, living in the high altitude city of Taif or a similar region in the Kingdom, such as Abha and Baha, which are located along the mountain line in the western part of Saudi Arabia (Figure 2). Most (more than 70) of the participating experts were recent graduates in the age group of 20-30 years. As far as the thermal comfort derived from the interview survey on the possibility to achieve thermal comfort in the higher altitude areas of Saudi Arabia was concerned, $20 \%$ of the participants believed that it was possible to achieve thermal comfort (TC) in modern buildings only in winter, while this number doubled for historical buildings in the same season. More than 100 experts argued that TC could be achieved even in some other seasons in modern $\mathrm{n}$ buildings and not just winter. Surprisingly, about half of this number suggested that TC could be achieved in historical buildings in some other seasons. It was observed that the feedback of the specialists varied. As a result, it might be beneficial to consider some other aspects such as years of experience and educational level. For instance, all the participants who mentioned that it was not possible to achieve TC in historical buildings at all had either 6-10 years or less than 5 years of experience. This showed that the years of experience in the field were quite crucial to obtain more accurate feedback. Similarly, most of the participants who voted that historical buildings could achieve TC in some seasons had more than 20 years of experience in the field (Figure 11). These findings will be analyzed and linked to investigation of experity impact of type of buildings in terms of historical and modern as well as years of experience on thermal comfort (Figures 12 and 13).

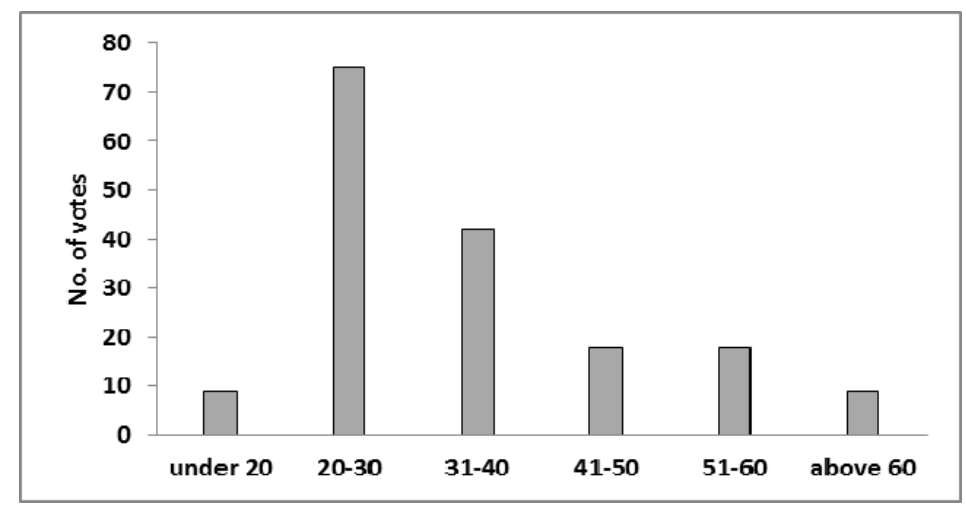

Figure 10. Age distribution of survey participants, i.e., architecture experts.

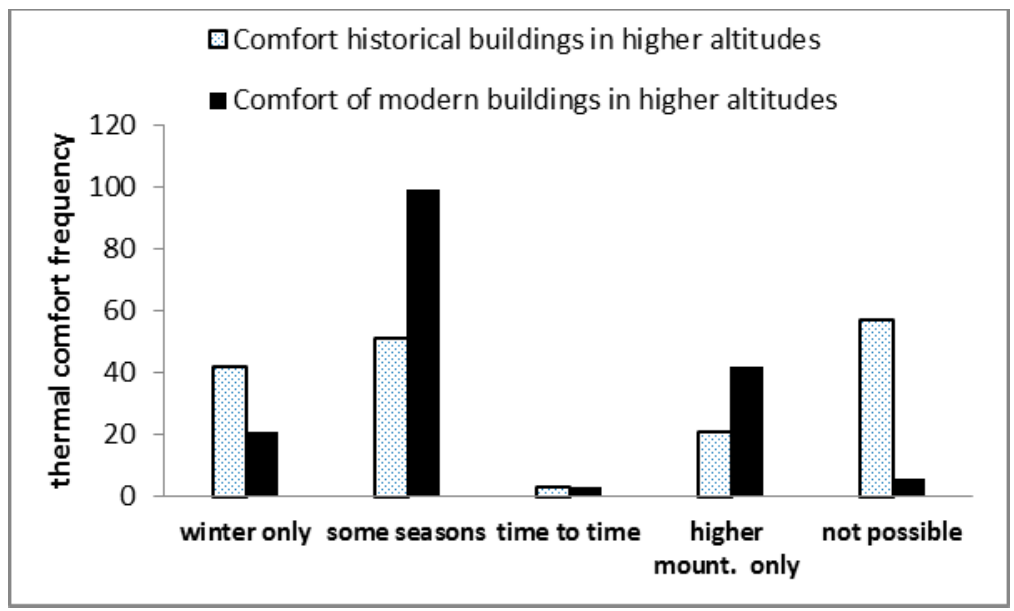

(A)

Figure 11. Cont. 


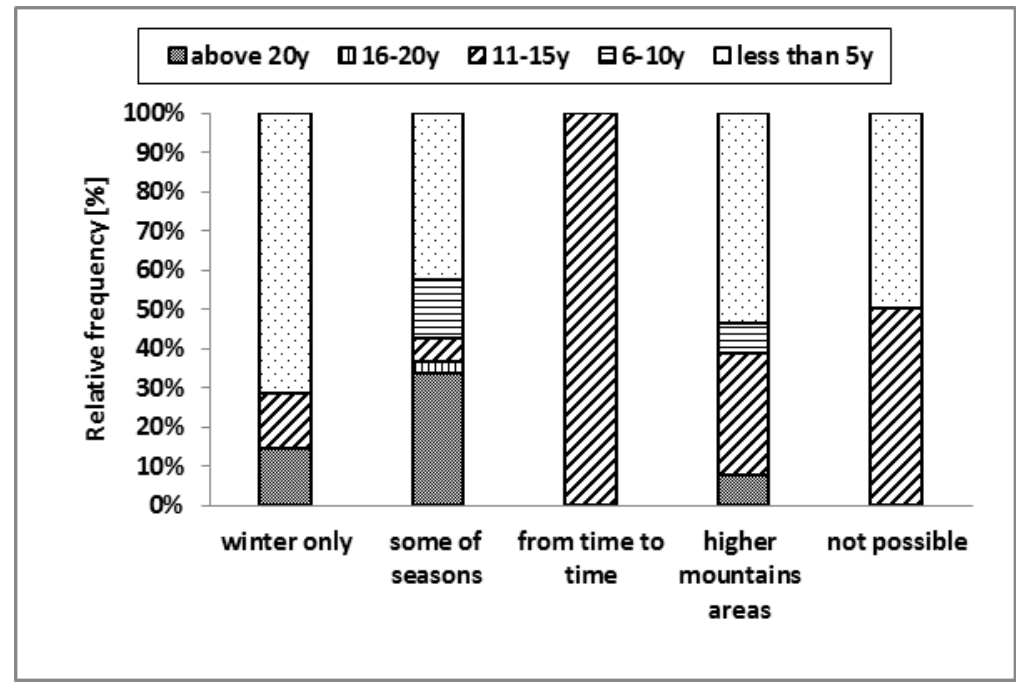

(B)

Figure 11. (A) Thermal comfort derived from interview survey on the possibility to achieve thermal comfort in the higher altitudes areas of Saudi Arabia. (B) Impact of years of experience on responses to questions asked regarding the thermal comfort at higher altitudes.

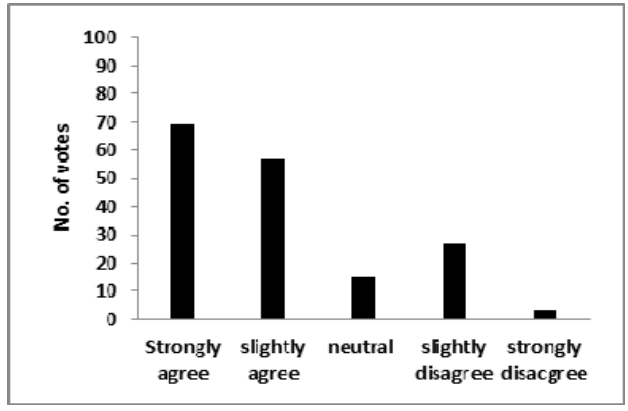

(A)

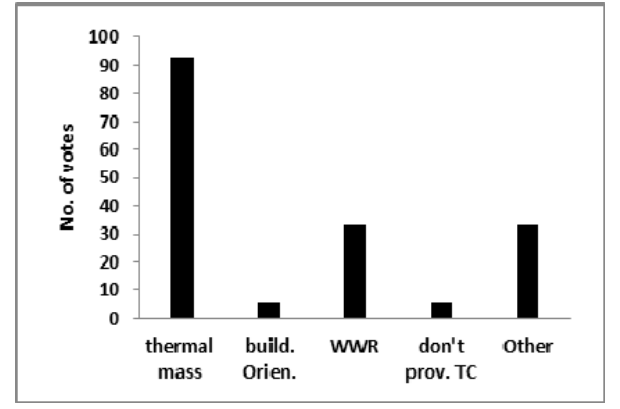

(B)

Figure 12. Responses of experts during the interview survey: (A) responses to the statement that historical and old buildings are better at providing thermal comfort than modern buildings in Saudi Arabia, and if agreed, (B) the most important elements identified.

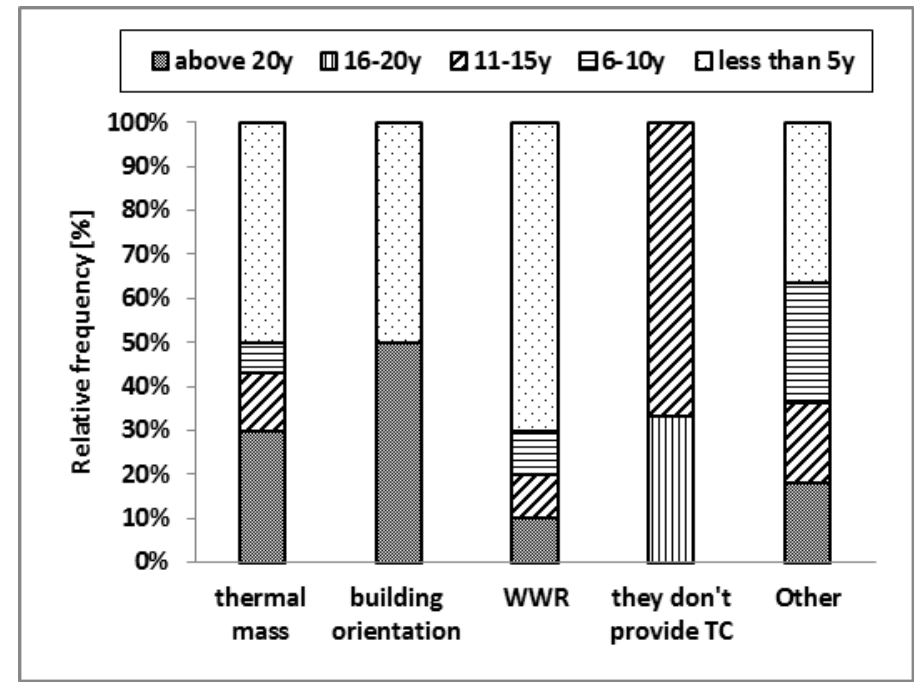

Figure 13. Impact of years of experience on responses to questions asked regarding the most important elements for providing comfort in historical buildings. 
Figure 12 shows the number of participants who stated that historical and old buildings were better at providing thermal comfort than modern buildings in Saudi Arabia, these findings also reflected clearly in Figure 16. This finding agreed with the findings reported in the previous sections. It implied that the age of the participants affected the accuracy of the feedback. Further, as shown in Figure 13, most of the participants stated that historical and old buildings are better at providing TC to the users because of the construction materials used as well as the design strategy. Figure 12B shows that thermal mass was by far the most important aspect with respect to the strategies affecting the building performance. The WWR came in second with approximately 30 votes, while the building orientation had a minor impact according to the survey. Figure 13 shows the effect of the number of years of experience on the feedback shown in Figure 12B. Surprisingly, most of the participants who believed that thermal mass were the most important element for providing TC had less than 5 years of experience, while most of the experts who had more than 20 years of experience chose the building orientation as the major element. However, these findings can be compared with latest publication on this subject in terms of parameters such as thermal mass, WWR, and orientation. As far as the thermal mass is concerned, there is abundant research published on it, considering its advantages, particularly in hot regions or where there are clear fluctuations in the outdoor air temperatures. In the hot climate of Hong Kong, Shan [27] investigated the influence of thermal mass on the cooling load and reported that it can reduce the energy consumption by up to $7.23 \%$. Furthermore, Albayyaa [26] investigated the impact of thermal mass in the cold climate of Australia and revealed that a total reduction of $58 \%$ can be achieved. Many publications have focused on the fact that thermal mass is more likely to be effective in hot regions, as the drawbacks of a high thermal mass may outweigh its advantages, which will lead to a high energy consumption [31]. Even in the cold and Mediterranean climate, thermal mass is usually used to reduce the amount of cooling load in summer [28] (Figure 14). WWR is also one of the major aspects in hot regions because of the high amount of solar energy, particularly considering the south and the west orientations [11]. Figure 15 shows the amount of solar radiation for the south-west, south-east, north-west, and the north-east orientations. It can be seen that the north and the south-west orientations were the ones that received a high amount of solar radiation of up to $5000 \mathrm{~W}$. This amount of solar radiation was consistent with the distribution of the heat transfer (Figure 15B). The heat loss was the maximum at $5 \mathrm{pm}$ with approximately $-1500 \mathrm{~W}$ at the outdoor temperature peak, which was at the same time at about $35^{\circ} \mathrm{C}$. In a study conducted by Alshuhail [13] in a similar climate of the UAE, the researcher showed that the south orientation contributes a $9.4 \%$ increase in the indoor air temperature. Figure 16 shows the pattern of the south and north orientations. Although both had a relatively similar peak, the fluctuation rate was different.

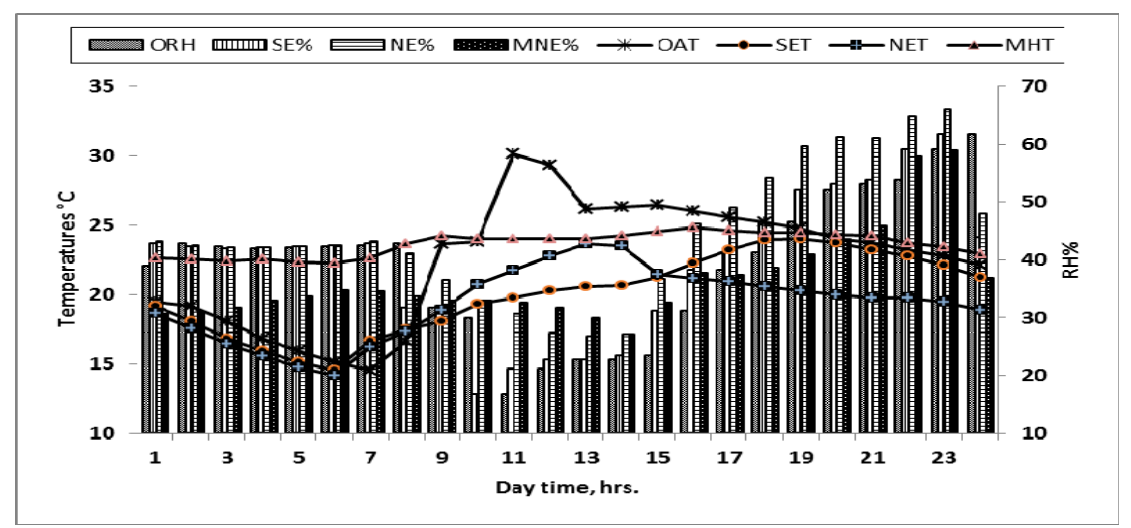

Figure 14. Indoor thermal monitoring of temperatures and relative humidity using data loggers installed in the palace during the field visit: MNE denotes the relative humidity in a modern house, ORH indicates the outdoor relative humidity, SE refers to the south-east humidity, NE represents the north-east humidity, OAT denotes the outdoor temperature, SET indicates the south-east temperatures, NET refers to the north-east temperatures, and MHT represents the recorded temperatures in a modern house. 


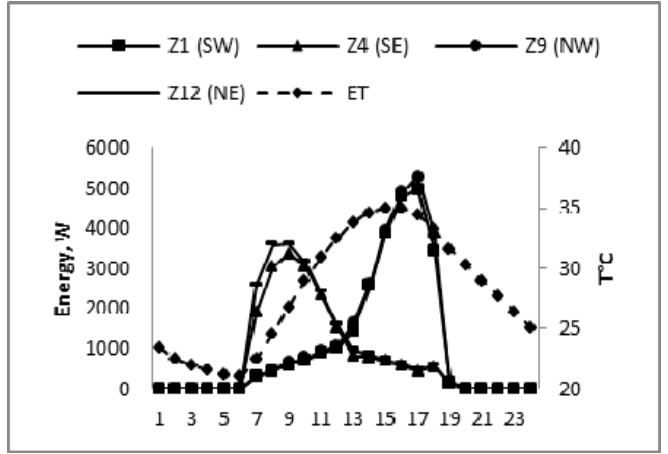

(A)

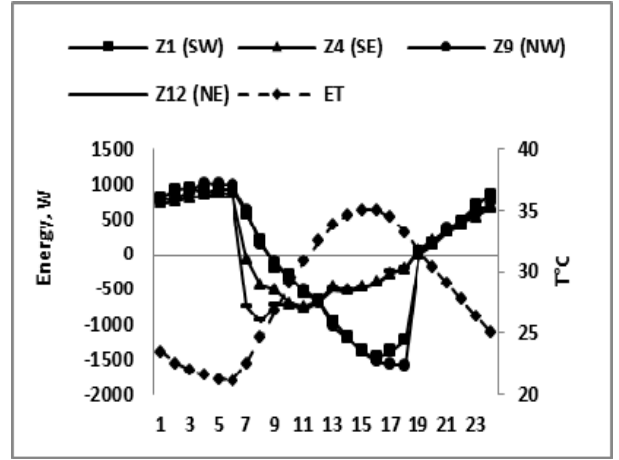

(B)

Figure 15. (A) Solar heat gain and (B) building heat transfer in some selected rooms in the palace, simulated using TAS EDSL in the south-west, south-east, and north-west zones.

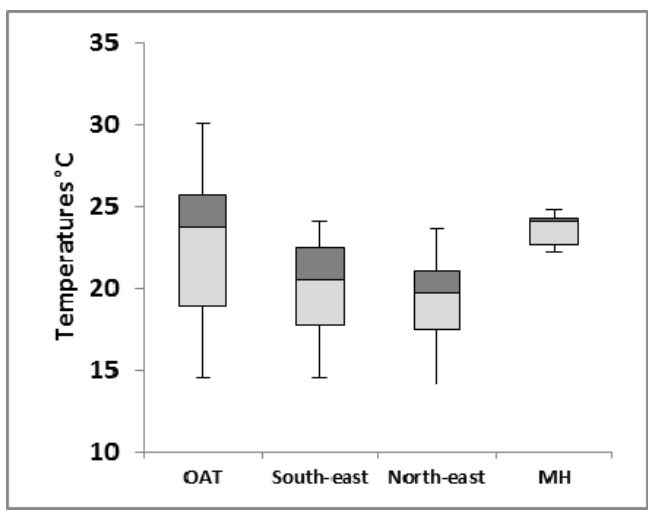

(A)

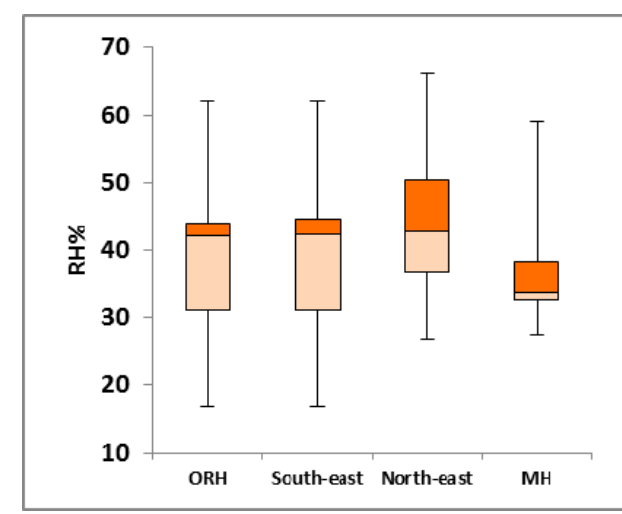

(B)

Figure 16. Box plots of (A) indoor air temperatures and (B) relative humidity of some selected rooms in the palace compared with a modern house and the outdoor air temperature on the experimental day.

With respect to the monitored indoor air temperature inside the palace and the modern house (Figure 14), it was observed that the orientation did not have a considerable impact on the indoor temperature; however, it influenced the thermal comfort sensation (Table 4 shows characteristics of used materials in both palace and modern building). It has to be mentioned that findings of Figure 16 is comparable with the findings of Deng [29] who found that the use of thermal mass has no effect on the energy load, but it affects thermal comfort. The current study showed that the use of thermal mass had a slight effect on the indoor air temperature, but it helped to provide thermal comfort to the users.

In a hot region with a high altitude, it was possible to achieve thermal comfort throughout most of the year, particularly when using a thermal mass construction building as in the case of Shubra Palace. The use of thermal mass helped to keep the external envelops cool in most of the seasons and in most of the orientations in summer. This helped to utilise the advantage of natural ventilation through the large windows in the palace. A thermal imaging camera was used to explore the influence of orientation on temperature in both traditional and modern building designs (Table 5). In the north-west orientation, the inner surface temperature gap was only $1{ }^{\circ} \mathrm{C}$, while in the south-east orientation, the gap increased to $6{ }^{\circ} \mathrm{C}$. This implied the influence of the orientation and the use of Mashrabiya which acted as the external shading devices. The study revealed that the influence of orientation was important in hot regions, and the south and the west were considered the worse orientations; however, precise consideration has to be implemented. Moreover, it was recommended to minimise the size of the windows in the south and the west orientations and to use external shading devices as in the case of the traditional buildings in the region. It was possible to achieve thermal comfort in such a region in modern buildings when learning from traditional buildings applying thermal mass, external shading 
devices, and building orientation were applied. Thermal comfort could be achieved throughout the year except in summer, when air conditioning might be required as the outdoor temperatures increase to above $35^{\circ} \mathrm{C}$. This would help to achieve nZEB in such a region, which relies heavily on mechanical means. In the experimental work conducted in Boqari palace, using evaporative cooling aid to bring indoor temperature to about $27^{\circ} \mathrm{C}$ with free running operation in summer (Table 6 and Figures 17 and 18). Figure 19 shows $24 \mathrm{~h}$. of indoor temperature monitoring.

Table 5. Comparison between a modern building (University Campus of Taif) and a historical building (Shubra Palace) in terms of inner surface temperatures recorded using thermal imaging cameras at $10 \mathrm{am}$ and $2 \mathrm{pm}$, in spring $2020,{ }^{\circ} \mathrm{C}$.

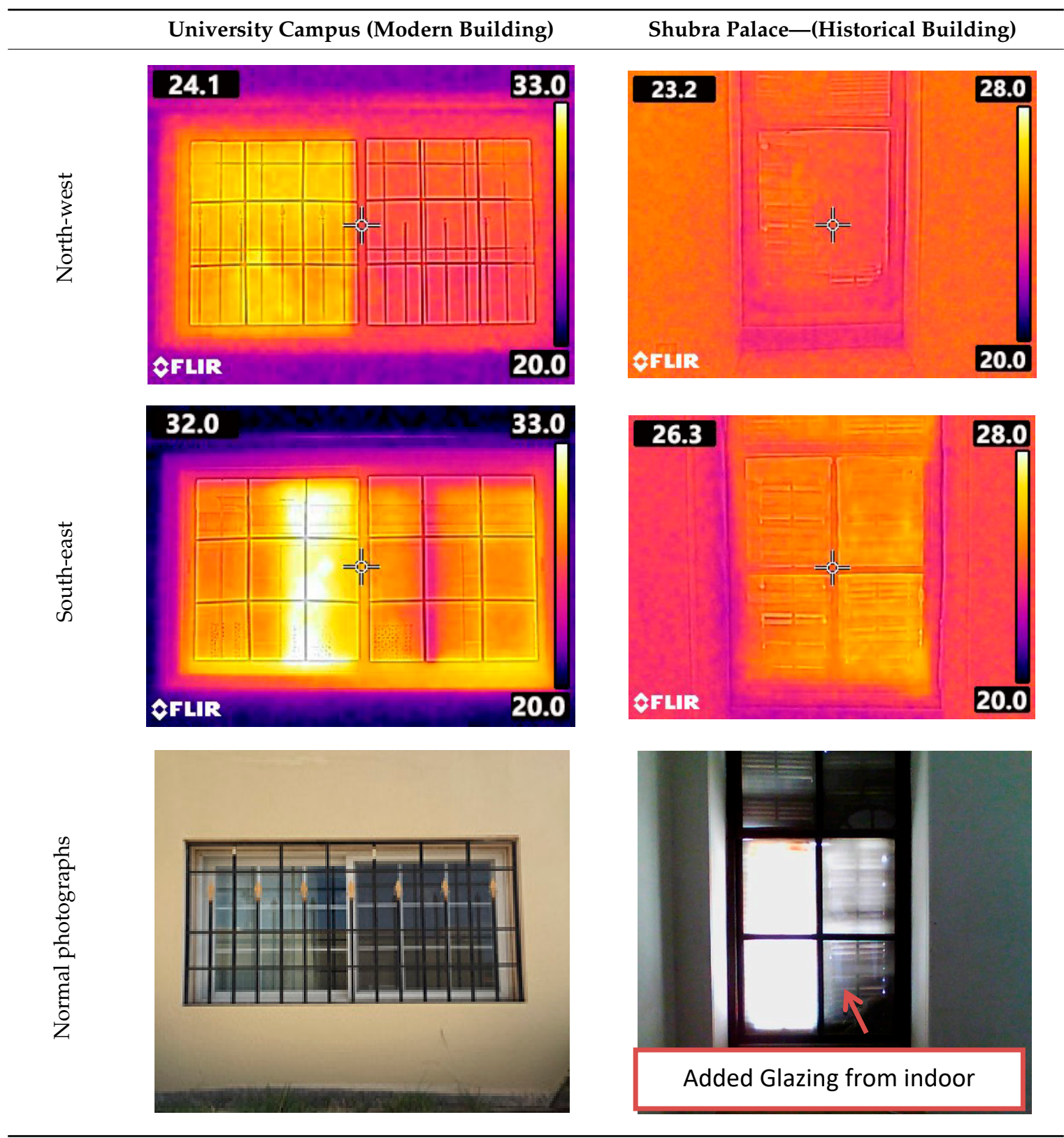


Table 6. Design and strategy of evaporative cooling and increasing air speed inside Boqari Palace.






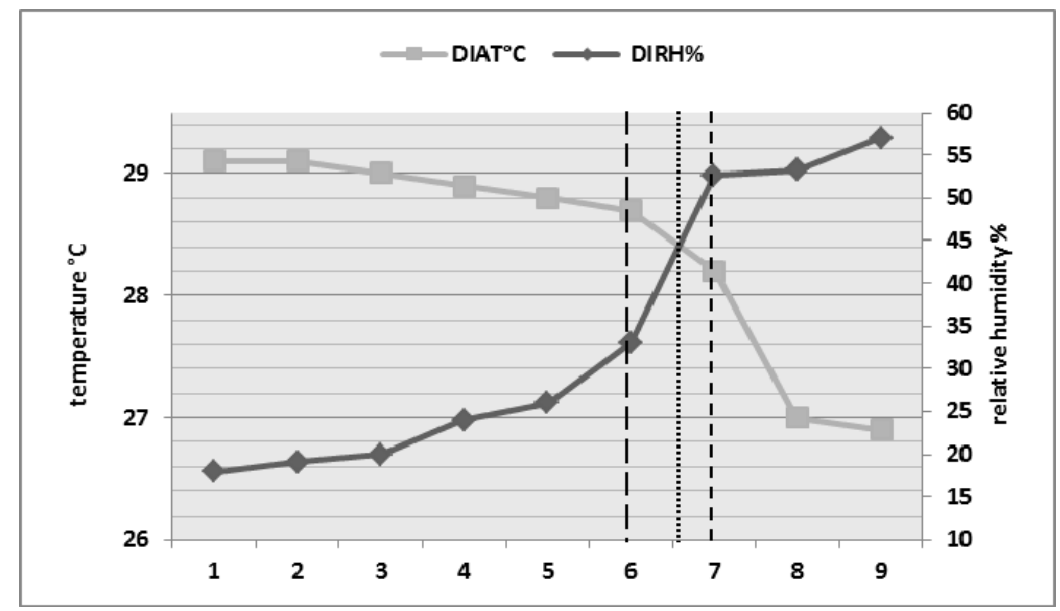

Figure 17. Distribution change in temperature and relative humidity while using water spray in a 5 min slots.

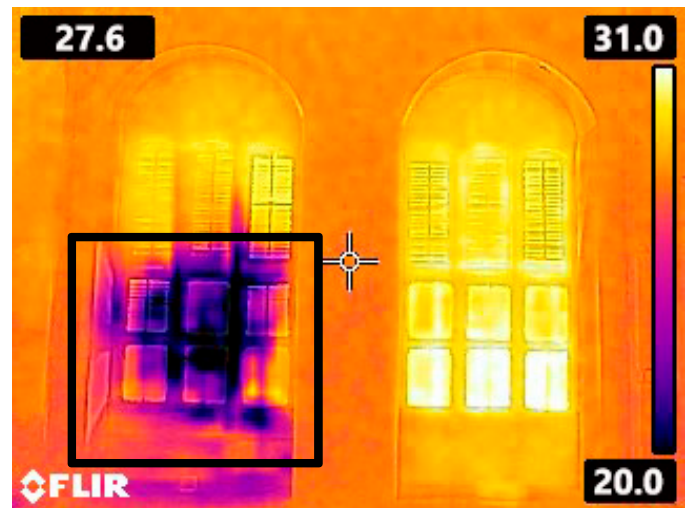

(A)

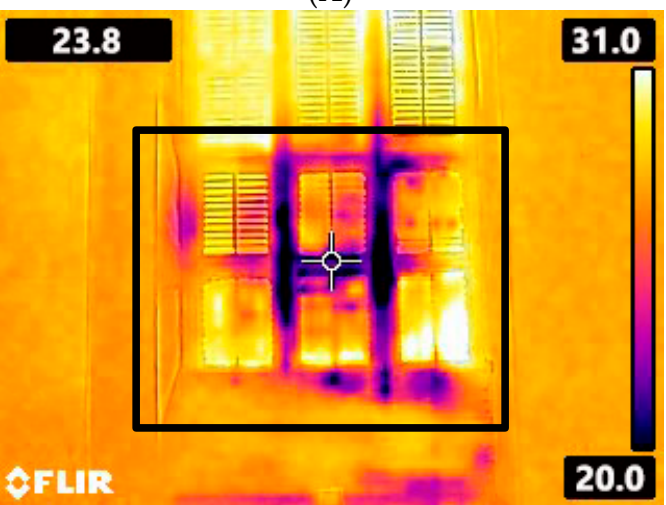

(C)

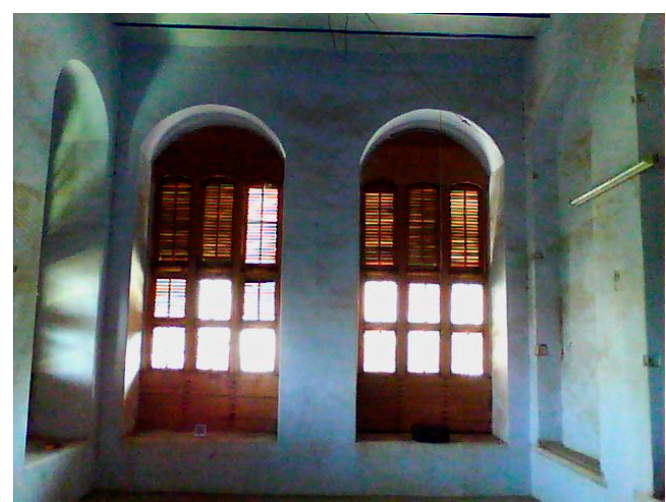

(B)

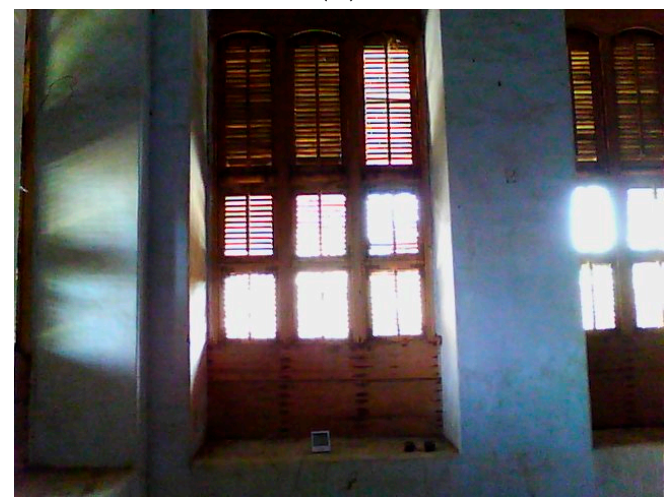

(D)

Figure 18. Impact of evaporative cooling on internal Mashrabiya using a thermal imaging camera, ${ }^{\circ} \mathrm{C}$. (A-D). 


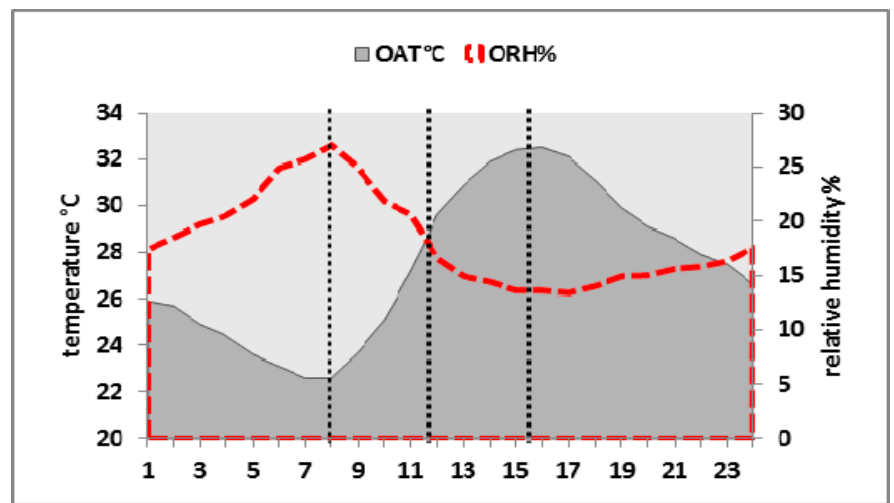

(A)

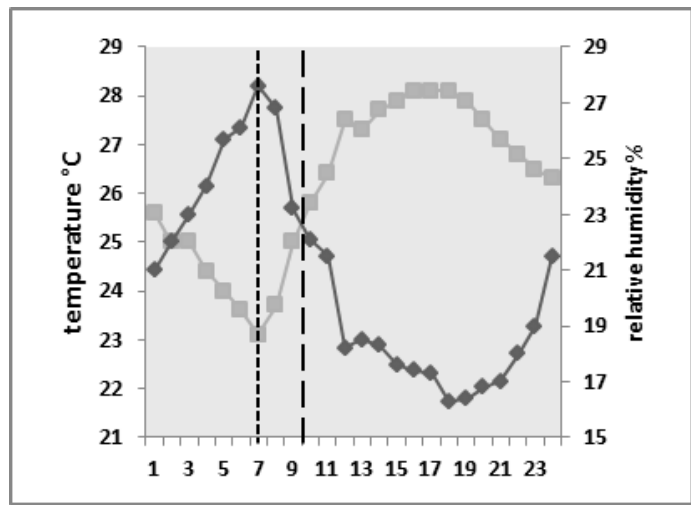

(B)

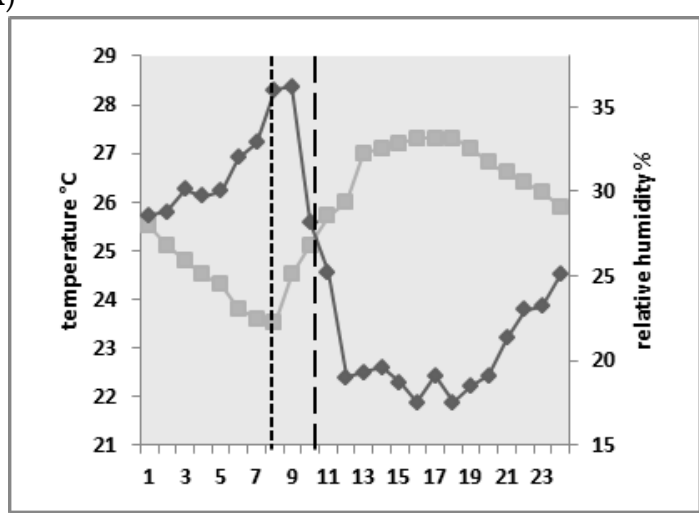

(C)

Figure 19. Free running indoor air temperatures and relative humidity inside Boqari Palace using data-loggers, where (A) is the actual external temperature, $(\mathbf{B})$ is the south indoor temperature and relative humidity facing room and $(\mathbf{C})$ is the north facing room.

The study of evaporative cooling shows a clear influence on indoor air temperature as well as relative humidity (Figure 17). The distribution of five minute monitoring results which for 9 slots shows a drop in air temperature of about $2{ }^{\circ} \mathrm{C}$ (from $29^{\circ} \mathrm{C}$ to $27^{\circ} \mathrm{C}$ ) and a considerable increase of relative humidity from only $19 \%$ to $55 \%$. The system aid significantly to improve the dryness in the indoor environment which has resulted in a major contribution to thermal comfort sensation. The use of thermal imaging camera also supported this outcome as it can be seen in Figure 18. Since the selected room is facing south, wood material attached to window system dropped temperature by $4{ }^{\circ} \mathrm{C}$. It can be reported that the use of evaporative cooling in hot region can contribute mostly on improving relative humidity and less impact is reported to indoor air temperature. However, the system can generally improve the thermal comfort preference indoors in free running buildings. In comparison between south and north facing rooms, the later has its temperature peaked at $27^{\circ} \mathrm{C}$ which is a one degree lower than south. This is $5^{\circ} \mathrm{C}$ lower than outdoor temperature reported in the same day. Considering international standards of comfort level, the suggested operative temperature of comfort introduced by ASHRAE-55 [61] $27^{\circ} \mathrm{C}$ is considered as within the comfort zone level. Similarly with ISO 7730 [62], it is worth mentioning that the $27^{\circ} \mathrm{C}$ is actually in upper limit of comfort suggested by international standards; however, it is still within acceptable level. As summertime, this is quite acceptable especially with range of relative humidity.

As far as increasing indoor air speed is concerned (ventilation), it can be noted that the experiment shows some improvement in the indoor thermal comfort by the mean of convection heat transfer with obviously no change in either indoor air temperature or relative humidity. It is recommended to use both techniques in hot and dry regions especially in higher altitude mountains where outdoor temperature in summer is not as high as other hot locations in the region. The system can contribute 
significantly to improve free running operation system which will have a clear impact on energy efficiency and thermal comfort in buildings.

\section{Conclusions}

This study investigated the advantages of historical buildings, taking into consideration the case study of Shubra Palace in the city of Taif (Saudi Arabia). The work explored the advantages of thermal mass and large windows with external shading devices designed and constructed on the basis of the local climate of the higher altitude mountains in the hot region. The elevation of this city makes the climate warm in summer and moderate in winter as compared to the other parts of the Arabian desert of Saudi Arabia. Various methods were used in this research. First of all, as the palace had no architectural drawings from since it was built, the research group aimed to provide the drawings as a contribution of this work (Figures 6 and 7). Along with the site observation, the indoor air temperature of the palace was monitored using data loggers. Furthermore, thermal imaging cameras were used to evaluate the physical patterns of the external walls. The building was compared with a modern house while monitoring the indoor air temperatures and relative humidity and compared with a modern university building while monitoring with external and internal thermal imaging cameras. The work also included a questionnaire interview with architecture experts. As the study involved analyzing a historical building which has never been examined before, it was beneficial to ask experts who know such buildings very well. The study led to the following results and recommendations:

- Duration of experience in a field is quite important to obtain more accurate feedback. The study found that as the years of experience increased, the feedback became more accurate.

- The study highlighted that the use of thermal mass had a slight effect on the indoor air temperature and energy consumption, but it helped to provide thermal comfort to the users.

- In a hot region with high altitude locations, it was possible to achieve thermal comfort during most of the year (autumn, winter, and spring), particularly when using a thermal mass construction building as in the case of Shubra Palace. However, air-conditioning systems might be necessary in summer because of the rise in the outdoor temperature to above $35^{\circ} \mathrm{C}$.

- The study showed that the influence of orientation was major in hot regions; the south and the west were considered the worse orientations because of the exposure of high solar radiation even at a high altitude.

- Glazing windows had a more significant effect on the indoor building environment than the thermal mass. As a result, the window system had to be taken into account precisely in hot regions, even at higher altitude locations.

- The use of external shading devices is recommended in larger windows to reduce the amount of solar radiation, particularly in the south- and the west-facing zones.

- The use of evaporative cooling can improve indoor thermal comfort significantly; it can lower indoor air temperature by $2{ }^{\circ} \mathrm{C}$ and relative humidity from $19 \%$ to $55 \%$ in about 45 min during the field experiment.

Author Contributions: M.A.: Conceptualization, Data curation, Writing—original draft. A.B.: investigation A.A.: review and editing, U.I. and I.S.: analysis, A.S. and M.A.-S.: research method, M.A.-H. and M.G. supervision. All authors have read and agreed to the published version of the manuscript.

Funding: The research was funded by the Deanship of Scientific Research, Taif University, Saudi Arabia grant number (1-441-108).

Acknowledgments: The authors would like to thank the students from Taif University, namely F. Alotibiy, A. Alshahrani, A. Alsufyani, M. Safder, A. Alshlwy, T. Althabetti and Y. Qhtani, who visited the site and participated in conducting the thermal imaging monitoring study during the course of Building Material. Furthermore, authors would like to express his sincere gratitude to Arch. Almoiad who worked on the Revit modelling. A special thanks to Saudi Commission for Tourism and National Heritage-Taif branch for providing us with the permission to conduct this research in the palace as part of its collaboration with the University of Taif, particularly, Arch. Rabi Aldilami for providing access to the palaces in all the site visits. Warm thanks is 
also extended to the 'Lafta' group from Taif University and other partisanship institutions, as this work is one of the contributions of this initiative to serve heritage buildings in Saudi Arabia. In addition, as part of the group, authors would like to thank students from King Abdulaziz University for conducting drawings of Boqari Palace, the team lead by Ahmad Khan.

Conflicts of Interest: The authors declare no conflict of interest.

\section{References}

1. Al-Khatri, H.; Alwetaishi, M.; Gadi, M.B. Exploring thermal comfort experience and adaptive opportunities of female and male high school students. J. Build. Eng. 2020, 31, 101365. [CrossRef]

2. Rackes, A.; Melo, A.P.; Lamberts, R. Naturally comfortable and sustainable: Informed design guidance and performance labeling for passive commercial buildings in hot climates. Appl. Energy 2016, 174, 256-274. [CrossRef]

3. Masoumi, H.R.; Nejati, N.; Ahadi, A.A. Learning from the Heritage Architecture: Developing Natural Ventilation in Compact Urban Form in Hot-Humid Climate: Case Study of Bushehr, Iran. Int. J. Arch. Herit. 2016, 11, 1-18. [CrossRef]

4. $\quad$ Feng, W.; Zhang, Q.; Ji, H.; Wang, R.; Zhou, N.; Ye, Q.; Hao, B.; Li, Y.; Luo, D.; Lau, S.S.Y. A review of net zero energy buildings in hot and humid climates: Experience learned from 34 case study buildings. Renew. Sustain. Energy Rev. 2019, 114, 109303. [CrossRef]

5. Scorpio, M.; Ciampi, G.; Rosato, A.; Maffei, L.; Masullo, M.; Almeida, M.; Sibilio, S. Electric-driven windows for historical buildings retrofit: Energy and visual sensitivity analysis for different control logics. J. Build. Eng. 2020, 31, 101398. [CrossRef]

6. Troup, L.; Phillips, R.; Eckelman, M.J.; Fannon, D. Effect of window-to-wall ratio on measured energy consumption in US office buildings. Energy Build. 2019, 203, 109434. [CrossRef]

7. Nikpour, M.; Kandar, M.Z.; Mosavi, E. Investigating Daylight Quality Using Self-Shading Strategy in Energy Commission Building in Malaysia. Indoor Built Environ. 2012, 22, 822-835. [CrossRef]

8. Alwetaishi, M. Impact of glazing to wall ratio in various climatic regions: A case study. J. King Saud Univ. Eng. Sci. 2019, 31, 6-18. [CrossRef]

9. Alghoul, S.K.; Rijabo, H.G.; Mashena, M.E. Energy consumption in buildings: A correlation for the influence of window to wall ratio and window orientation in Tripoli, Libya. J. Build. Eng. 2017, 11, 82-86. [CrossRef]

10. Kaasalainen, T.; Mäkinen, A.; Lehtinen, T.; Moisio, M.; Vinha, J. Architectural window design and energy efficiency: Impacts on heating, cooling and lighting needs in Finnish climates. J. Build. Eng. 2020, 27, 100996. [CrossRef]

11. Alwetaishi, M.; Taki, A. Investigation into energy performance of a school building in a hot climate: Optimum of window-to-wall ratio. Indoor Built Environ. 2019, 29, 24-39. [CrossRef]

12. Asfour, O.S. A comparison between the daylighting and energy performance of courtyard and atrium buildings considering the hot climate of Saudi Arabia. J. Build. Eng. 2020, 30, 101299. [CrossRef]

13. Alshuhail, K.; Taleb, H.M. Thermal performance and experimental assessment of building orientations in the United Arab Emirates (UAE). Sci. Technol. Built Environ. 2020, 26, 1461-1489. [CrossRef]

14. Liping, W.; Hien, W.N. The impacts of ventilation strategies and facade on indoor thermal environment for naturally ventilated residential buildings in Singapore. Build. Environ. 2007, 42, 4006-4015. [CrossRef]

15. Su, X.; Zhang, X. Environmental performance optimization of window-wall ratio for different window type in hot summer and cold winter zone in China based on life cycle assessment. Energy Build. 2010, 42, 198-202. [CrossRef]

16. Marino, C.; Nucara, A.; Pietrafesa, M. Does window-to-wall ratio have a significant effect on the energy consumption of buildings? A parametric analysis in Italian climate conditions. J. Build. Eng. 2017, 13, 169-183. [CrossRef]

17. Feng, G.; Chi, D.; Xu, X.; Dou, B.; Sun, Y.; Fu, Y. Study on the Influence of Window-wall Ratio on the Energy Consumption of Nearly Zero Energy Buildings. Procedia Eng. 2017, 205, 730-737. [CrossRef]

18. Sayed, M.A.A.E.D.A.; Fikry, M.A. Impact of glass facades on internal environment of buildings in hot arid zone. Alex. Eng. J. 2019, 58, 1063-1075. [CrossRef]

19. Al-Saggaf, A.; Nasir, H.; Taha, M. Quantitative approach for evaluating the building design features impact on cooling energy consumption in hot climates. Energy Build. 2020, 211, 109802. [CrossRef] 
20. Shahbazi, Y.; Heydari, M.; Haghparast, F. An early-stage design optimization for office buildings' façade providing high-energy performance and daylight. Indoor Built Environ. 2019, 28, 1350-1367. [CrossRef]

21. Lartigue, B.; Lasternas, B.; Loftness, V. Multi-objective optimization of building envelope for energy consumption and daylight. Indoor Built Environ. 2013, 23, 70-80. [CrossRef]

22. Hao, L.; Herrera-Avellanosa, D.; Del Pero, C.; Troi, A. What Are the Implications of Climate Change for Retrofitted Historic Buildings? A Literature Review. Sustainability 2020, 12, 7557. [CrossRef]

23. Bandera, C.F.; Pachano, J.; Salom, J.; Peppas, A.; Ruiz, G.R. Photovoltaic Plant Optimization to Leverage Electric Self Consumption by Harnessing Building Thermal Mass. Sustainability 2020, 12, 553. [CrossRef]

24. Darmanis, M.; Çakan, M.; Moustris, K.; Kavadias, K.; Nikas, K.-S.P. Utilisation of Mass and Night Ventilation in Decreasing Cooling Load Demand. Sustainability 2020, 12, 7826. [CrossRef]

25. Wolisz, H.; Kull, T.M.; Müller, D.; Kurnitski, J. Self-learning model predictive control for dynamic activation of structural thermal mass in residential buildings. Energy Build. 2020, 207, 109542. [CrossRef]

26. AlBayyaa, H.; Hagare, D.; Saha, S. Energy conservation in residential buildings by incorporating Passive Solar and Energy Efficiency Design Strategies and higher thermal mass. Energy Build. 2019, 182, 205-213. [CrossRef]

27. Shan, K.; Wang, J.; Hu, M.; Gao, D.-C. A model-based control strategy to recover cooling energy from thermal mass in commercial buildings. Energy 2019, 172, 958-967. [CrossRef]

28. Rodrigues, E.; Fernandes, M.S.; Gaspar, A.R.; Gomes, Á.; Costa, J.J. Thermal transmittance effect on energy consumption of Mediterranean buildings with different thermal mass. Appl. Energy 2019, 252, 113437. [CrossRef]

29. Deng, J.; Yao, R.; Yu, W.; Zhang, Q.; Li, B. Effectiveness of the thermal mass of external walls on residential buildings for part-time part-space heating and cooling using the state-space method. Energy Build. 2019, 190, 155-171. [CrossRef]

30. Kumar, S.; Singh, M.K.; Mathur, A.; Mathur, S.; Mathur, J. Thermal performance and comfort potential estimation in low-rise high thermal mass naturally ventilated office buildings in India: An experimental study. J. Build. Eng. 2018, 20, 569-584. [CrossRef]

31. Reilly, A.; Kinnane, O. The impact of thermal mass on building energy consumption. Appl. Energy 2017, 198, 108-121. [CrossRef]

32. Li, Y.; Yam, J.C.W. Designing Thermal Mass in Naturally Ventilated Buildings. Int. J. Vent. 2004, 2, 313-324. [CrossRef]

33. Ghoreishi, A.H.; Ali, M.M. Parametric study of thermal mass property of concrete buildings in US climate zones. Arch. Sci. Rev. 2013, 56, 103-117. [CrossRef]

34. Csáky, I.; Kalmár, F. Investigation of the relationship between the allowable transparent area, thermal mass and air change rate in buildings. J. Build. Eng. 2017, 12,1-7. [CrossRef]

35. Shafigh, P.; Asadi, I.; Mahyuddin, N. Concrete as a thermal mass material for building applications-A review. J. Build. Eng. 2018, 19, 14-25. [CrossRef]

36. Kumar, S.; Tewari, P.; Mathur, S.; Mathur, J. Development of mathematical correlations for indoor temperature from field observations of the performance of high thermal mass buildings in India. Build. Environ. 2017, 122, 324-342. [CrossRef]

37. Mousa, W.A.Y.; Lang, W.; Yousef, W.A. Simulations and quantitative data analytic interpretations of indoor-outdoor temperatures in a high thermal mass structure. J. Build. Eng. 2017, 12, 68-76. [CrossRef]

38. Perini, K. Retrofitting with vegetation recent building heritage applying a design tool—The case study of a school building. Front. Arch. Res. 2013, 2, 267-277. [CrossRef]

39. Jiao, J.; Xia, Q.; Shi, F. Nondestructive inspection of a brick e timber structure in a modern architectural heritage building: Lecture hall of the Anyuan Miners' Club, China. Front. Archit. Res. 2019, 8, 348-358. [CrossRef]

40. Li, Y.; Xu, P. Thermal Mass Design in Buildings-Heavy or Light? Int. J. Vent. 2006, 5, 143-150. [CrossRef]

41. Ghoulem, M.; El Moueddeb, K.; Nehdi, E.; Zhong, F.; Calautit, J. Analysis of passive downdraught evaporative cooling windcatcher for greenhouses in hot climatic conditions: Parametric study and impact of neighbouring structures. Biosyst. Eng. 2020, 197, 105-121. [CrossRef]

42. Suwannapruk, N.; Prieto, A.; Janssen, C. "Desigrated"-Desiccant Integrated Façade for the Hot-Humid Climate of Bangkok, Thailand. Sustainability 2020, 12, 5490. [CrossRef] 
43. Alaidroos, A.; Krarti, M. Experimental validation of a numerical model for ventilated wall cavity with spray evaporative cooling systems for hot and dry climates. Energy Build. 2016, 131, 207-222. [CrossRef]

44. Alaidroos, A.; Krarti, M. Optimized controls for ventilated wall cavities with spray evaporative cooling systems. Energy Build. 2017, 154, 356-372. [CrossRef]

45. Bagasi, A.A.; Calautit, J.K. Experimental field study of the integration of passive and evaporative cooling techniques with Mashrabiya in hot climates. Energy Build. 2020, 225, 110325. [CrossRef]

46. Kang, D.; Strand, R.K. Analysis of the system response of a spray passive downdraft evaporative cooling system. Build. Environ. 2019, 157, 101-111. [CrossRef]

47. Tejero-González, A.; Esquivias, P.M. Personalized Evaporative Cooler to Reduce Energy Consumption and Improve Thermal Comfort in Free-Running Spaces. Sustainability 2019, 11, 6451. [CrossRef]

48. Arab News. ThePlace: Shoubra Palace, First Historical Palace in KSA's Highland City of Taif. Available online: https://www.arabnews.com/node/1588406/saudi-arabia (accessed on 9 June 2020).

49. Priyadarsini, R.; Hien, W.N.; David, C.K.W. Microclimatic modeling of the urban thermal environment of Singapore to mitigate urban heat island. Sol. Energy 2008, 82, 727-745. [CrossRef]

50. Berger, T.; Amann, C.; Formayer, H.; Korjenic, A.; Pospichal, B.; Neururer, C.; Smutny, R. Impacts of external insulation and reduced internal heat loads upon energy demand of offices in the context of climate change in Vienna, Austria. J. Build. Eng. 2016, 5, 86-95. [CrossRef]

51. Resuli, P.; Dervishi, S. Thermal Performance of Cultural Heritage Italian Housing in Albania. Energy Procedia 2015, 78, 753-758. [CrossRef]

52. Carlini, M.; Zilli, D.; Allegrini, E. Simulating Building Thermal Behaviour: The Case Study of the School of the State Forestry Corp. Energy Procedia 2015, 81, 55-63. [CrossRef]

53. Pino, A.; Bustamante, W.; Escobar, R.; Pino, F.E. Thermal and lighting behavior of office buildings in Santiago of Chile. Energy Build. 2012, 47, 441-449. [CrossRef]

54. Dudkiewicz, E.; Fidorów-Kaprawy, N. The energy analysis of a hybrid hot tap water preparation system based on renewable and waste sources. Energy 2017, 127, 198-208. [CrossRef]

55. Kendrick, C.; Ogden, R.; Wang, X.; Baiche, B. Thermal mass in new build UK housing: A comparison of structural systems in a future weather scenario. Energy Build. 2012, 48, 40-49. [CrossRef]

56. Zoras, S.; Veranoudis, S.; Dimoudi, A. Micro- climate adaptation of whole building energy simulation in large complexes. Energy Build. 2017, 150, 81-89. [CrossRef]

57. Gucyeter, B. Evaluating diverse patterns of occupant behavior regarding control-based activities in energy performance simulation. Front. Arch. Res. 2018, 7, 167-179. [CrossRef]

58. Clarke, J. Energy Simulation in Building Design, 2nd ed.; Butterworth Heuemann: Oxford, UK, 2001.

59. Fabrizio, E.; Monetti, V. Methodologies and Advancements in the Calibration of Building Energy Models. Energies 2015, 8, 2548-2574. [CrossRef]

60. Alwetaishi, M.; Kamel, M.; Al-Bustami, N. Sustainable applications of asphalt mixes with reclaimed asphalt pavement (RAP) materials: Innovative and new building brick. Int. J. Low Carbon Technol. 2019, 14, 364-374. [CrossRef]

61. ASHRAE. Thermal Environmental Conditions for Human Occupancy; Proposed Addendum D to Standard 55-2004; ASHRAE: Peachtree Corners, GA, USA, 2008.

62. ISO. Ergonomics of the Thermal Environment-Analytical Determination and Interpretation of Thermal Comfort Using Calculation of the PMV and PPD Indices and Local Thermal Comfort Criteria; ISO 7730; ISO: Geneva, Switzerland, 2006.

Publisher's Note: MDPI stays neutral with regard to jurisdictional claims in published maps and institutional affiliations.

(C) 2020 by the authors. Licensee MDPI, Basel, Switzerland. This article is an open access article distributed under the terms and conditions of the Creative Commons Attribution (CC BY) license (http://creativecommons.org/licenses/by/4.0/). 